\title{
İbrahim Gülşenî’nin Farsça Tevhidi: Tanıtım ve Tenkitli Neşir
}

\author{
Elif NAMOĞLU ÇEVIKKER* \\ Esra YÖRDEM***
}

Öz

Anadolu'nun etkili tasavvuf ekollerinden biri olan Halvetiliğin Gülşenîlik kolunun kurucusu İbrahim Gülşenî, üç dilde şiir yazmış önemli bir şair ve sûfîdir. Tasavvufi ve edebî kişiliğiyle öne çıkan şair, siyasi kimliği ile de göze çarpmaktadır. Yaşamını Diyarbakır, Tebriz ve Mısır'da geçiren Gülşenî, döneminin önemli şair, âlim ve devlet adamları ile tanışmış; kısa zamanda Türk tasavvuf tarihinin önemli ve etkili bir ismi olmuş ve Türkçe, Farsça ve Arapça olarak yazdığı manzum eserlerle de adından söz ettirmiştir. Bugüne kadar eserlerinden bazıları tez ve makale olarak yayımlanmış olan şairin Farsça eserleri arasında Mevlânâ’nın etkisinin açıkça görüldüğü, Mesnevî’ye nazire olarak kaleme alınan Ma'nevî’si, Farsça rubai ve tuyuğlardan oluşan Kenzü'l-cevâhir adlı eseri ve Farsça Divan'ı bulunmaktadır. Bu çalışmada İbrahim Gülşenî’nin Farsça eserleri arasından Farsça Divan'ındaki tevhidin incelenmesi ve tenkitli neşrinin yapılması amaçlanmıştır. Çalışmada öncelikle Gülşenî’nin hayatı ve eserleri hakkında kısaca bilgi verildikten sonra tevhidin içerik değerlendirmesi yapılmış ve dört yazma eserden faydalanılarak tenkitli neşri gerçekleştirilmiş̧ir.

Anahtar Kelimeler: İbrahim Gülşenî, Farş̧a Divan, Tevhid, Tasavvuf, Şiir.

\footnotetext{
* Dr. Öğr. Üyesi, İstanbul Medeniyet Üniversitesi, Edebiyat Fakültesi, Doğu Dilleri ve Edebiyatları Bölümü, Fars Dili ve Edebiyatı Anabilim Dalı, Türkiye.

Elmek: elif.namoglu@medeniyet.edu.tr https://orcid.org/0000-0002-0696-4180.

** Dr. Öğr. Üyesi, İstanbul Medeniyet Üniversitesi, Edebiyat Fakültesi, Doğu Dilleri ve Edebiyatları Bölümü, Fars Dili ve Edebiyatı Anabilim Dalı, Türkiye.

Elmek: esra.cakar@medeniyet.edu.tr

https://orcid.org/0000-0002-8008-2127.
} 


\title{
The Critical Edition of Persian Tawhid Written by İbrahim Gülşeni
}

\begin{abstract}
İbrahim Gülşeni, the founder of the 'Gülşeni' sect, branch of Halvetism, one of the effective Sufi schools of Anatolia, is an important poet and sufis who wrote poetry in three languages. Standing out with his mystical and literary personality, the poet also standed out with his political identity. Spending his life in Diyarbakır, Tabriz and Egypt, Gülșeni met important poets, scholars and statesmen of his time; soon became an important and influential name in the history of Turkish sufism and made a name for himself in verse works written in Turkish, Persian and Arabic. Some of his works, which have been published as a thesis and article so far, include Manevi, which the influence of Mevlana was clearly visible, Kenzu'l-cevahir and Persian Divan. In this study, it is aimed to introduce the Persian Divan among the Persian works of İbrahim Gülşeni and the Persian tawhid within this Divan and to prepare the critical edition of the tawhid. After giving brief information about the poet's life and works in the study, the evaluation of the tawhid was made, and in the end, the critical edition was presented by making use of four manuscripts.
\end{abstract}

Keywords: İbrahim Gülşeni, Persian Divan, Tawhid, Sufism, Poetry. 


\section{Extended Summary}

The founder of the 'Gülşeni' sect, sufi and poet İbrahim Gülşeni lived in the last half of the 15th century and in the first half of the 16th century. The most important work that gives information about his life is 'Menakıb-1 İbrahim Gülşeni', which was written by Muhyi Gülşeni. Although there are different information about the date of birth and place of birth, according to the information mentioned, he was born in Diyarbakır in 826/1423 and died in Egypt in 940/1534.

His father Sheikh Muhammad al-Amidi was a scholar who had works on fiqh, kalam, logic and sufism. Her mother Hediyetullah was the daughter of Molla Serefuddin, who was a teacher in Aintab. After his father passed away, his uncle Seydi Ali interested in his education. He studied madrasa in Tabriz and started to be called Molla İbrahim. After finding the opportunity to meet Akkoyunlu Sultan Uzun Hasan (d. 882/1478), he held important positions. Meanwhile, meeting with the sheikh Dede Ömer Ruşeni (d. 892/1487) completely changed his life. Dede Ömer Ruşeni declared him the successor and put him in charge of the sect. Sultan Yakup (d. 896/1490), who passed to the throne of Akkoyunlu after the death of Uzun Hasan, also respected Gülşeni. After the death of Sultan Yakup, İbrahim Gülşeni went to pilgrimage in 900/1495 with many of his followers due to the throne fights that appeared in the Akkoyunlu dynasty. Here he met some Egyptian scholars. He returned to Diyarbakır because of Shah Ismail's capture of Tabriz. Here he began to write his work which is called "Manevi". İbrahim Gülşeni went to Cairo from here and met with Memluk Sultan Kansu Gavri (d. 922/1516). The Memluk Sultan respected him and made a shrine for the sheikh. Gülşeni started his activities in this dervish lodge. When the Ottoman sultan Yavuz Sultan Selim (d. 926/1520) conquered Egypt, he visited him and allocated land to the sheikh. İbrahim Gülşeni continued his guidance activities in this dervish lodge called 'Gülşeniyye Asitane'. Due to a large number of disciples gathered around him, he was complained to Kanuni Sultan Süleyman (d. 974/1566) and was invited to Istanbul with the thought that he could make a revolt. In 935/1528-29, İbrahim 
Gülşeni, who came to Istanbul with his son Ahmed Hayali and his two caliphs, had the opportunity to meet with Kanuni Sultan Süleyman and the Sultan respected to him. İbrahim Gülşeni, who stayed in Istanbul for a year, lived for another 5 years after returning to Egypt and died on 940/23 April 1534.

İbrahim Gülşeni who wrote various works in three languages (Arabic, Persian and Turkish) studied religious and mystical issues in his works. The effects of Mevlana, Yunus Emre (d. 720/1320?), Nesimi (d. 820/1417?), Hafiz Şirazi (d. 792/1390) and Sheikh Dede Ömer Ruşeni can be seen in these works. Among his Turkish works: The "Turkish Divan", which contains more than 24 thousand couplets; the "Pend-name", which gives advices to the reader; "Çoban-name" which is located in the Masnavi of Mevlana whose subject is about "Shepherd and Hz. Musa"; "Tahkikat-ı Gülşeni", where sufistic issues are discussed; "The Seniority" which was written in the form of masnavi; and "Simurgname". His Arabic work: Arabic Divan which is consisting of 10 thousand couplets in response to İbnu'l-Far1z's (d. 632/1235) work 'Ta 'iyyetü'lKübra'. And his Persian works: "Kenzu'l-Cevahir" which is written in the form of rubai, and where religious and sufistic issues are explained; "Manevi" which was written in response to Mevlana's Masnavi and "Persian Divan".

In this study, the criticized edition of the Persian tawhid within the Persian Divan of İbrahim Gülşeni is presented and analysed. As it is known, tawhid is a literary genre that deals with the existence and unity of Allah. In this verse, which consists of 320 couplets, İbrahim Gülşeni focused on the existence and unity of God, his attributes, force, greatness, creation of the universe and human beings. He praised the Prophet with various attributes, who was sent as a mercy to the worlds. While explaining all of these, İbrahim Gülşeni made quotations from Quran and hadiths, mentioned some sufi principles like "unity of existence" and also his sufi thought. In his couplets, he emphasized that a person must clear his heart from all desires and aspirations, must be know the opportunity when alive and understand the meaning of die before dying by taking out the suspicions from heart. At the same time, he stated that on the way to reach God person must be aware of own weakness. Also since humankind will lose his way without a guide, a guide is necessary in order not to leave the right way. In this respect, Gülşeni mentioned his own sheikh Ruşeni with praise. 


\section{Giriş}

Halvetiliğin Gülşeniyye kolunun kurucusu olan İbrahim Gülşenî’nin hayatına dair ilk bilgileri Muhyî-i Gülşenî tarafından kaleme alınan Menâkıb-ı İbrahim Gülşenî adlı çalışmadan ediniyoruz. Bu eser bir menakıbname olmasına rağmen tarihsel bilgiler de barındırmaktadır. Önemli bir tarikat büyüğü olan İbrahim Gülşenî, aynı zamanda hacimli manzum eserlere sahip bir şairdir. Şairin Türkçe ve Arapça divanları hakkında tezler hazırlanmış, eserlerinden bazıları makale suretinde neşredilmiştir. Rubai ve tuyuğlardan oluşan Kenzü'l-Cevâhir adlı eseri ve Farsça Divan'ı hakkında ise bugüne kadar herhangi bir çalışma yapılmamakla birlikte elimizde sadece Mevlânâ'nın Mesnevî̀ sine nazire olarak yazılmış olan hacimli eseri Ma'nevî ile ilgili La'lî Mehmed Fenâî tarafından eserin ilk 500 beytine yapılmış olan şerhin neşri bulunmaktadır. ${ }^{1}$ İbrahim Gülşenî gibi önemli bir mutasavvıfın düşünce dünyasının anlaşılabilmesi şüphesiz eserlerinin tümünün tenkitli neşirlerinin gerçekleşmesi ile mümkün olacaktır. Bu bağlamda Gülşenî’nin Farsça Divan’ı Dr. Öğr. Üyesi Turgay Şafak ile birlikte tarafımızdan çalışılmaktadır. Bu çalışmanın bir başlangıcı olarak, bahsi geçen Divan içinde yer alan Farsça tevhidin tenkitli neşri hazırlanmış ve incelemesi yapılmıştır. Mesnevi nazım şeklinde kaleme alınan bu manzume, Gülşenî’nin Farsça şiirinden ve Farsça şiirinde yer vermiş olduğu tasavvufi düşüncesine dair bir numune teşkil etmesi bakımından önem arz etmektedir. Gülşenî’nin Farsça tevhidinin tenkitli neşrine geçmeden önce hayatı ve eserlerine dair bilgiler ile Farsça Divan'ın tespit edilen nüshalarının tanıtımı yapılacaktır.

\section{1. İbrahim Gülşenî (ö. 940/1534)}

\subsection{Hayatı}

15. yüzyılın ilk yarısı ile 16. yüzyılın ilk yarısında yaşamış olan İbrahim Gülşenî’nin hayatına dair bilgi veren en önemli kaynak Muhyî-i Gülşenî tarafından kaleme alınmış Menâkıb-ı İbrahim Gülşenî (Muhyî-i Gülşenî 2014) adlı 
eserdir. Muhyî-i Gülşenî onun nerede ve hangi tarihte doğduğuna dair herhangi bir bilgi vermemiştir ancak 940/1534 y1lında vefat ettiğini ve bu esnada 114 yaşında olduğunu dile getirmiştir. Bu ifadelere göre 826/1423 yılında doğmuş olmas1 gerekir. (Konur 2000: 105; Azamat 2000: 301; Muhyî-i Gülşenî 2014: 13) Gülşenî'nin hayatına dair bilgi veren bir diğer kaynak da, Mehmed Sami’nin Esmâru Esrâr (Sami 1316: 28) adlı eseridir. Buradaki bilgilere göre İbrahim Gülşenî 826/1423 yılında dünyaya gelmiş, 114 yıl yaşamış ve 940/1534 yılında vefat etmiştir. Nev'izâde Atâi (ö. 1045/1635) herhangi bir kaynak göstermeden onun 830/1427 tarihinde doğduğunu dile getirir. (Nev'izâde Atâyî 2017: 389) Doğum tarihi gibi doğum yeri hakkında da farklı görüşler mevcuttur. Bunlardan biri onun Diyarbakır'da dünyaya geldiğidir. Babasının türbesinin burada olmas1 bu görüşü desteklemektedir. Bursalı Mehmet Tahir, Osmanlı Müellifleri adlı eserinde onun 830/1427 tarihinde Diyarbakır'da doğduğunu ifade etmektedir. (Bursalı Mehmet Tahir 2016: 16) Muhammed Ali Terbiyet ise Danişmendân-ı Azerbaycan adlı kitabında onun aynı tarihte Berdaa'da doğduğunu dile getirmiştir. (Terbiyet 1377: 458)

Babası Şeyh Muhammed el-Âmidî fıkıh, kelam, mantık ve tasavvuf ile ilgili eserleri bulunan bir âlimdir. (Azamat 2000: 302) Baba tarafından soyu Oğuz Kağan'a dayandırılan İbrahim Gülşen̂̂'nin annesi ise Antep'te müderrislik yapan Molla Şerefüddîn'in kızı Hediyyetullâh'tır. ${ }^{2}$ (Konur 2000: 104; Muhyîi-i Gülşenî 2014: 13)

Babası vefat ettikten sonra amcası Seydî Ali onun yetiştirilmesi ile ilgilenmiştir. Dört yaşına geldiğinde Kur'ân-ı Kerim'i hatmetmiş, tefsir ve hadis kitapları okumakla meşgul olmuştur. On beş yaşına geldiğinde ise tefsir, kelam, hadis, matematik, edebiyat ve mantık gibi ilimleri öğrenmek için Maveraünnehir'e doğru yola çıkmış fakat Tebriz'e vardığında Akkoyunlu sultanı Uzun Hasan'ın (ö. 882/1478) kazaskeri Molla Hasan ile karşılaşmış ve Molla Hasan, İbrahim Gülşenî’yi Tebriz'de kalmaya ikna etmiştir. Burada aldığı medrese eğitiminden sonra İbrahim Gülşenî artık Molla İbrahim adıyla anılmaya başlamıştır. (Konur 2000: 105; Azamat 2000: 302) Uzun Hasan ile tanışma imkânı bulduktan sonra önemli görevlerde bulunmuş ve Uzun Hasan tarafından kendisine her an huzura girip çıkabilmesi için tarhan 
unvanı verilmiştir. (Konur 2000: 106; Azamat 2000: 302)

Hayatını değiştiren en önemli olay ise mürşidi Dede Ömer Ruşenî (ö. 892/1487) 3 ile tanışmasıdır: Uzun Hasan'ın Karabağ’da bulunan kardeşi Üveys (ö. 880/1475), derviş kıyafeti ile Tebriz'e gelir. Sultan Hasan başındaki tacın kime ait olduğunu sorar. Üveys tacın Halvetî şeyhi Dede Ömer Ruşenî’ye ait olduğunu söyler ve ondan övgüyle bahseder. Uzun Hasan onu görmeyi arzu eder ve şeyhi davet için İbrahim Gülşen̂̂’yi Karabağ’a gönderir. Ruşenî ile karşılaşan Gülşenî ona hayran kalır ve şeyhe intisap eder. (Muhyî-i Gülşenî 2014: 16) Dede Ömer Ruşenî’nin Tebriz'e gelişi Uzun Hasan döneminde olduğu için İbrahim Gülşenî, 1478 yılından önce şeyhe intisap etmiş olmalıdır. Bu dönemden sonra şiddetli bir cezbe hali yaşayan Gülşenî, şeyhinin gözetimi altında seyr-u sülûkunu tamamlamıştır. Dede Ömer Ruşenî, vefatından birkaç gün önce (ö. 892/1487) Gülşen̂̂’yi postnişini ilan edip tarikatın başına geçirmiştir. (Azamat 2000: 302; Konur 2000: 109)

Uzun Hasan'ın vefatından sonra Akkoyunlu hükümdarı olan Sultan Yakup (ö. 896/1490) da Gülşen̂̂’ye saygı göstermiş ve askerin maneviyatını artırmak için bazı savaşlarda onu da beraberinde götürmüştür. Sultan Yakup'un 896/1490 yılında vefatından sonra Akkoyunlu hanedanı içinde taht kavgaları baş göstermiştir. Bu süre içinde İbrahim Gülşenî beraberinde çok sayıda müridiyle 900/1495 yılında hacca gitmiştir. Mekke'de bazı Mısırlı âlimlerle tanışma imkânı bulmuştur. Gülşenî hac ziyaretinden sonra Tebriz'e dönmüş fakat Şah İsmail (ö. 930/1524)'in 907/1502'de Tebriz'i ele geçirmesi sebebiyle ailesini de yanına alarak Diyarbakır'a dönmüştür. (Azamat 2000: 302; Tek 2009: 26) Kaynaklarda yer alan ifadelere göre burada Mevlânâ (ö. 672/1273)'nın Mesnevî’sine nazire olarak kaleme aldığı Ma nevî adlı eserini yazmaya başlamıştır. Diyarbakır'dan Maraş'a giden İbrahim Gülşenî oradan Kudüs'e gitmek üzere hareket etmiştir. Nefis terbiyesi için burada 40 gün kadar halvette kaldıktan sonra Mısır'a gitme kararı almıştır. Mısır'da Kahire yakınlarında bulunan Birketü'l-Hac adlı yerde bir süre konaklamıştır. Burada Memlük Sultanı Kansu Gavrî (ö. 922/1516) ile görüşmüştür. Kansu Gavrî şeyhe hürmet göstermiş ve kendisine Kubbetü'l-Mustafa adlı yerde küçük bir tekke yaptırmıştır. (Azamat 2000: 302; Tek 2009: 26; Muhyî-i Gülşenî 2014: 23) İbrahim Gülşenî burada irşad faaliyetlerine başlamıştır. Yavuz Sultan Selim (ö. 926/1520) Mısır'ı fethettiğinde 
şeyhi ziyarette bulunmuş ve bir isteği olup olmadığını sormuştur. İbrahim Gülşenî de Müeyyediyye Camii yakınlarında bulunan Bergavallık adlı arazinin kendilerine tahsis edilip bir dergâh yapılmasını rica etmiştir. 926/1519-20 yılında başlanan tekke inşaatı 931/1524-25 yılında tamamlanmıştır. Bu tekke Gülşeniyye Âsitâne’si adıyla bilinmektedir. (Hulvî 1993: 531 - 532; Konur 2000: 130)

Kanuni Sultan Süleyman (ö. 974/1566) zamanında Misır valisi Ahmed Paşa (ö. 930/1524)'nın isyanı bastırıldıktan sonra 931/1525 yılında Sadrazam İbrahim Paşa (ö. 942/1536) Mısır'a gönderilmiştir. Bölgenin ileri gelen kişileri ve bazı şeyhler kendisini ziyaret etmiş olmasına rağmen İbrahim Gülşenî ziyaret için oğlu Ahmed Hayalî (ö. 977/1570)'yi göndermiştir. Bu durumdan memnun olmayan İbrahim Paşa şeyh hakkında inceleme başlatmış ve şeyhin çok sayıda müridi olduğunu ve bir isyan çıkaracağını düşündüğünü belirterek şeyhi İstanbul'a getirtmiştir. İbrahim Paşa, 935/1528-29 yılında oğlu Ahmed Hayalî ve iki halifesi ile İstanbul'a gelen İbrahim Gülşenî hakkında çeşitli araştırmalarda bulunmuş ve Ma 'nevîadlı eserini Kemalpaşazâde (ö. 940/1534)'ye inceletmiştir. Şeyh hakkında olumsuz bir şey öğrenemeyen İbrahim Paşa, onu padişahla görüştürmeden Mısır'a geri gönderme düşüncesinde olmasına rağmen şeyh, Kanuni Sultan Süleyman ile görüşme firsatını bulmuştur. Padişah bu olaydan haberdar olmuş ve şeyhe hürmet göstermiş hatta artık görmez olan gözlerini tedavi ettirmiştir. Bir yıl İstanbul'da kalan İbrahim Gülşenî, Mısır'a döndükten sonra beş yıl daha yaşamış ve 9 Şevval 940/23 Nisan 1534 tarihinde vefat etmiştir. Ölümüne ebced hesabıyla şu tarih düşürülmüştür: "Mâte kutbü’z-zamân İbrâhîm."” (Azamat 2000: 303; Konur 2000: 129; Muhyî-i Gülşenî 2014: 26) Hulvî diğer kaynaklardan farklı olarak Gülşenî’nin vefat tarihini 964/1556-57 olarak kaydetmiştir. (Hulvî 1993: 537)

\subsection{Eserleri}

Eserlerinde dinî ve tasavvufi konuları işleyen İbrahim Gülşenî Arapça, Farsça ve Türkçe olmak üzere üç dilde çeşitli eserler kaleme almıştır. Bu eserlerde Mevlânâ, Yunus Emre (ö. 720/1320 ?), Nesîmî (ö. 820/1417 ?), Hâfiz-1 Şirâzî (ö. 792/1390) ve şeyhi Dede Ömer Rûşenî’nin etkileri görülmektedir. 


\subsubsection{Türkçe Eserleri}

Türkçe Divant: 24 binden fazla beyti ihtiva eden bu eser hem edebî açıdan hem de dil bakımından büyük önem taşımaktadır. İbrahim Gülşenî’nin Türkçe Divan'1 Mehmet Akay tarafından doktora tezi olarak çalışılmıştır. (Akay 1996) Ayrıca Betül Sinsoysal tarafından da yüksek lisans tezi hazırlanmıştır. (Sinsoysal 2017) Pend-nâme: Tasavvufi konuların işlendiği bu eserde dünya nimetlerine karşı gösterilmesi gereken tavır, aşk, muhabbet, iyilik, çalışma ve melamet gibi konular anlatılmaktadır. Okuyucuya nasihat ve ögüt veren bir eserdir. (Konur 2000: 177; Tek 2009: 40) Bu eser Alim Yıldız tarafından makale olarak çalışılmıştır. (Yıldız 2002) Çoban-nâme: İbrahim Gülşenî bu eserinde Mevlânâ'nın Mesnevî'sinde yer alan "Çoban ile Hz. Musa" hikâyesini işlemektedir. (Konur 2000: 178; Azamat 2000: 304; Tek 2009: 40) Tahkikat-ı Gülşen̂̂: Tasavvufi konuların işlendiği mensur bir eserdir. Eser içinde Mevlânâ ve Attar gibi bazı mutasavvıflardan şiirler şerh edilmiştir. (Konur 2000: 178; Azamat 2000: 304; Tek 2009: 40; Sinsoysal 2017: 8) Kıdemnâme: İbrahim Gülşenî mesnevi tarzda kaleme aldığı bu eserinde Allah'ın beka âleminin tek hâkimi olduğu, insanın yaratılışı, kâinatın varlığı, insanların Allah'a karşı vazifeleri, ölüm ve kıyamet gününde insanların yeniden diriltilip bir araya getirilmesi gibi tasavvufi konuları anlatmaktadır. Bu eserin Mehmet Sait Çalka tarafından incelenerek tenkitli metni hazırlanmıştır. (Çalka 2017) Sîmurgnâme: Muhyî bu eserin 30 bin beyit olduğunu ifade etmektedir. (Azamat 2000: 304; Akben 2012: 499)

\subsubsection{Arapça Eserleri}

Arapça Divanı: Arapça şiirlerinde Halîlî mahlasını kullanan İbrahim Gülşenî’nin İbnü'l-Fârız'nn (ö. 632/1235) et-Tâ'iyyetü'l-Kübrâ'sına nazire olarak kaleme aldığı 10 bin beyitlik divanıdır. Gülşenî, bu eserinde şathiyat tarzında şiirler kaleme almıştır. (Akay 1996: XXXI-XXXII; Azamat 2000: 304; Konur 2000: 178; Tek 2009: 42) Bu eser Abdullah Kızılcık tarafından yayınlanmıştır. (Kızılcık 2006)

\subsubsection{Farsça Eserleri}

Kenzü'l-Cevâhir: Rubai ve tuyuğ nazım şekilleriyle kaleme alınan bu eserde dinî ve tasavvufi konular sade bir dille anlatılmıştır. Yaklaşık olarak 7500 
beyitten ibarettir. Ma'nevî: İbrahim Gülşenî bu eserini Mevlânâ Celaleddîn-i Rûmî'nin Mesnevî̀sine nazire olarak kaleme almıştır. Remel bahrinde yazd1ğ1 eser yaklaşık olarak 40 bin beyitten ibarettir. Bu eserin ilk 500 beyti La'lî Mehmed Fenâî (ö. 1112/1700-01) tarafından şerh edilmiştir. (Tek 2009) Farsça

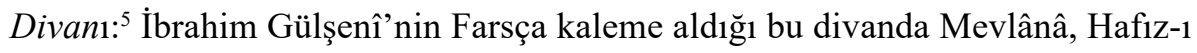
Şirâzî ve Yunus Emre'nin etkisi görülmektedir.

\section{Gülşenî’nin Farsça Tevhidi}

İbrahim Gülşenî’nin mesnevi nazım şekliyle kaleme almış olduğu Farsça tevhidi Farsça Divan'ı içinde yer alır. Toplam 320 beyitten oluşan tevhidin ilk 64 beyti aruz vezninin mefâ' îlün mefầ̂̂lün fe'ûlün kalıbı, 65 . beyitten itibaren ise fầ'ilâtün fầ'ilâtün fầ'ilün kalıbı ile yazılmıştır. Aşağıda, tenkitli neşrini hazırladığımız manzumede anlatılan silsileye uyarak tevhidin muhtevasına dair bilgiler verilecektir.

\subsection{Muhtevası}

Şair manzumeye; gönülden dünya bağı kopartılmadığı sürece zikrin, ibadetin bir manasının olmayacağını ifade ettiği beyti ile başlar:

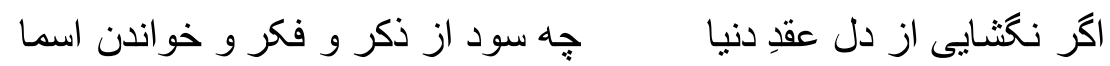

Gönülden dünya bağını çözmezsen; zikrin, fikrin ve esmâ-i hüsnâ okumanin ne faydast var? (b. 1)

Gülşenî burada zikrin, ibadetin hakiki olması için kişinin kendi varllğı dâhil gönlünde yer eden her türlü dünyevi bağdan kurtulması gerektiğini vurgular. Beytin devamında tevhid türünün konusu gereği olan Allah'ın varlığı ve birliği, kudreti, yüceliği, eşsizliğinin dile getirilmesi ile isim ve sıfatları, kâinattaki tezahürleri, kâinatın ve insanoğlunun yaratılışı üzerinde durulur. Kâinattaki tüm varlıklar şüphesiz Yaradan'ın sıfat ve makamına işaret eder. İlahi hakikatleri idrak ve müşahede etmek yani ilahi sırra vâkıf olmak güçtür. Sır, müşahede mahalli olarak bilinir ve mana itibariyle mevcuttur. İlahi sır, zahiri idraki mümkün olmayan ancak batınî manası ile gönül ehli ve keşf sahiplerinin 
idrak edebildiği hakikattir. (Kuşeyrî 2012: 169, 182; Uludağ 2012: 317) Gülşenî, beyitlerinde bu hakikate vurgu yapar. Gülşenî'nin ifadesine göre Yaradan'1 idrak, diğer tüm idraklerin ötesindedir ve idrak edilebilecek olan, Yaradan'ın muhabbetinin zevkidir; bu zevke de herkesin varabilmesi mümkün değildir. Allah'ın yaratma kudretinden bir sır, ruhların yaratıldığı yani beyitlerde 'dem' diye tabir edilen elest (Allah'ın ruhları yarattıktan sonra sorduğu, "Elestü bi-rabbiküm" (Ben sizin Rabbiniz değil miyim?) diye sorulduğu zaman) anıdır. 'Dem' için kullanılan bir başka anlam da; "Hakk'ın feyzinden ibaret olan Rahmanî nefes" ve "tecellinin zuhur anı"dır. Mevlevîlerde buna"Hû" denmektedir. (Uludağ 2012: 102) Bu manada manzumede tevhid sırlarının anlatımı ve kavranmasına yönelik Hallac-1 Mansûr'un adı anılır:

$$
\begin{aligned}
& \text { نكنجد جون انا اندر دمِ هو } \\
& \text { انا جِبود نكنجد دم در آن دم }
\end{aligned}
$$

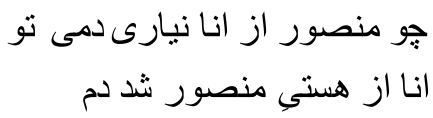

Mansur gibi ben (ene) 'den söz edemezsen senin benliğin (enâniyyet) onun nefesine (نفخت فيه من روحى) nasıl slğar? Ene, Mansur'un varllğı için yaratıldl. Ene nedir? Üflemek (نفخت (ن) dahi Ene sirrına idrak anına siğmaz ve anlaşılmaz. (b. 12)

Beyitte ben'den yani kendi varlığından bahseden bir kimsenin dem anına yani hakikati içeren tek gerçek zamana erişemeyeceği vurgulanmaktadır.

Allah'ın gücü ve kudreti, sıfatları uçsuz bucaksız ummana/deryaya benzetilir. (Uludağ 2012: 64) İnci elde etmek yani vahdet sırrına ermek için bu denize gark olmak gerekir. Böylece vahdet sırrına eren insan-1 kâmil 'Mutlak Varlık'a karışır. Gülşenî, gayb âleminde gizlenmiş ve şehadet âleminde seçkin olarak bulunan Mutlak Varlık'ı bir eşi görülmemiş, eşi benzeri olmayan inci tasviri ile ifade eder. (b. 15-22) Bu benzetmenin ifade edildiği beyitlerde "Gizli bir hazine idim. Bilinmeyi istedim..." kudsî hadisine işaret vardır. (b. 15, 16, 21) Yine şair, vahdeti temsil etmede 'güneş' benzetmesine de yer verir:

جو خور فرديّت از ناكزيرست دُرى كو از يتيمى بىنظيرست

$O$, eşi benzeri olmayan bir incidir; güneş gibi, birliği kaçınlmazdır. (b. 22) Vahdet-i vücûd ve vahdet-i şühûd görüşlerinin yansıtıldığı beyitlerden 
sonra varlığın ilki ve tüm güzelliklerin tecellisi, insanoğlunun özü olarak anılan Hz. Peygamber (sav)'den, kâinat ve mevcudatın yaratılışından bahsedilir. (b. 3164) Yukarıda zikredildiği üzere "gizli bir hazine" olan Mutlak Varlık, Hakikat-i Muhammediyye'de zuhur etmiş; tüm eşya O'nun veçhinden görünür olmuştur. (b. 36-47) Allah'ın yaratma kudreti ifade edilirken " كن فكان" (kün fe-kân) kav-

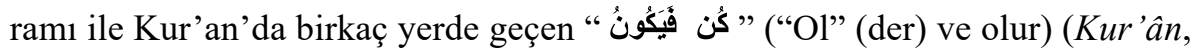
Bakara 2/117, Âl-i İmrân 3/47, 59, En'âm 6/73, Nahl 16/40, Meryem 19/35, Ya$\sin$ 36/82, Mü'min 40/68) ayetine işaret edilir. (b. 53) Hz. Muhammed, "Hakk'ın zat âleminden ilk tecellisi olan, diğer âlemlerin kendisinden zuhur ettiği ilk yaratılan nur" (Ayverdi 2005) anlamında akl-1 küll olarak nitelendirilir ve beyitte "levlak" şeklinde geçen "levlake levlake lemâ halaktu'l-eflâk" (Sen olmasaydın, felekleri yaratmazdım) anlamındaki hadise telmihte bulunulur. (b. 58)

Gülşenî, devamında kendi cezbe hâline değinmekle birlikte müritlere ilahi sırra ulaşmada rehber olabilecek çeşitli nasihatler ve bilgileri içeren beyitlere yer verir.

Gülşenî’de İbn Arabî (ö. 638/1240), İbn Fârız (ö. 632/1235) ve Mevlânâ'nın (ö. 672/1273) düşünceleriyle şekillenmiş olan vahdet-i vücûd anlayışı açık şekilde görülür. "Vahdet-i vücûd, Allah'tan başka hakikî hiçbir vücûd kabul etmeyen, bütün varlıkları Mutlak Vücûd'un isim ve sıfatlarının tezahürü, tecellisi sayarak hakikî varlığa nazaran onların ezelî ve ebedî yokluğu ifade ettiğini keşif ve tecrübe yoluyla ortaya koyan tasavvufi bir meslektir." (Erdem 1990: 38) İlahi tecelliye gark olmuş olan Gülşenî, sözüne ilahi surlardan bahisle devam edeceğinden saliklere kendisini can kulağı ile dinlemelerini öğütler. Zira bahsedeceği şeyler, her iyi kimsenin kulağına küpe olacak, ilahi denizden çıkan mana incileridir. His gözüyle görülmesi

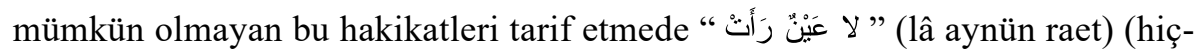

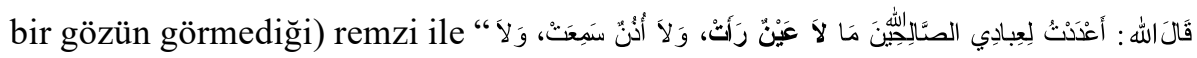

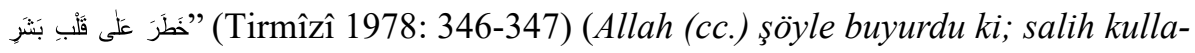
rım için hiçbir gözün görmediği, hiçbir kulağın işitmediği ve hiçbir insanın hatır ve hayaline gelmemiş olan nimetler hazırladım.) hadisine işaret vardır. (b. 88) $\mathrm{Bu}$ hakikatler visal yani Allah'a ulaşma yolunda bilinmesi gereken şeylerdir.

Gülşenî’ye göre tevhid inancı, bilinci ve ilahi sırların bilinmesi ancak kalp gözü ve akıl kulağı ile mümkündür. Çünkü his kulağı buna sağırdır; his gözü ise kör ve şaşıdır. Bu körlük, kalpte zan ve şüpheye yer verenlerde olur. Münkirlerin bu karanlığı ise kaçınılmazdır. Zira kör, doğru yolu inkâr eder. (b. 273-276) 
Adem yani yokluk, Vücûd'un yani varlığın zıddını ifade eder. Gülşenî, salikin yokluk gibi saf/arınmış olması ve varlığından hiçbir eser bulunmaması gerektiği üzerinde durur:

$$
\begin{aligned}
& \text { بهر دركي اين بيان آماده شو... } \\
& \text { كى ز حالٍ نيستان يابى خبر ... } \\
& \text { جون علم صافى روان و ساده شو }
\end{aligned}
$$

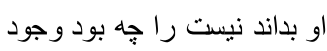

$$
\begin{aligned}
& \text { تا ازين هنتى تو دارى بود دود اثر }
\end{aligned}
$$

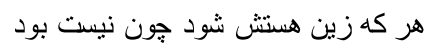

Yokluk gibi saf ve sade ol; bu beyanı anlamak için hazır ol... Sende bu varlıktan eser oldukça; yokluktan/yokluk hâlinden nasıl haberin olsun... Her kim varlığından yok olursa; varlı̆̆ yoklukla bilir. (b. 105, 107, 112)

Yani varlığından bir iz bulunduğu müddetçe kişinin yokluktan haberdar olabilmesi mümkün değildir.

Gülşenî, yine bu manayı idrak ve Mutlak Varlık'a ulaşmak için verdiği öğütlerde; kişinin tüm dünyevî bağlarından kurtulması, kalbini selim kılıp tüm heva, hırs ve heveslerden arındırıp saf ve temiz tutması, zan ve şüpheyi gönlünden atması gerektiğini söyler:

$$
\begin{aligned}
& \text { كى لدن تعليم يابى از عليم } \\
& \text { تا نكردى صاف قلب و دل سليم }
\end{aligned}
$$

Kalbini saf gönlünü selim kllmadan ledünden nasll haberin olsun? (b. 123)

Şair, kişiyi cehennemde rüsva eden şeyin kalbinin saf/temiz olmamasından kaynaklandığını ifade eder. Kur'ân' da Hesap/Kıyamet Günü, 'bazı yüzlerin parladığı [beyazladığı, ağardığı] ve bazı yüzlerin karardığı’ gün şeklinde şöyle geçer:

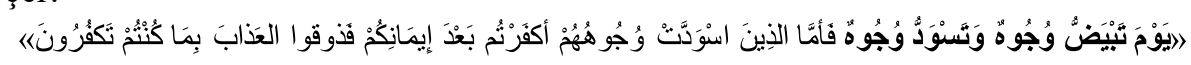

"Bazı yüzlerin parladığg [beyazladığı, ağardığ1] ve bazı yüzlerin karardığ1 o (Hesap) Günü’nde yüzleri kararanlara: 'İmana erdikten sonra hakikati inkâr mı ettiniz? O hâlde hakikati inkâr ettiğiniz için tadın bu azabı!' (denilecek)” (Kur 'ân, Âl-i İmrân 3/106) (Esed 2009: 167)

Yüzdeki bu karalığın kalpteki karalığın yansıması olduğunu ifade eden Gülşenî, zikredilen ayete iki yerde iktibas yapar:

$$
\begin{aligned}
& \text { اي بسا قلبى كزو رسو اشود } \\
& \text { آتش دوزخ براى غش بود }
\end{aligned}
$$

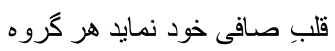

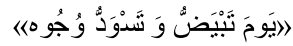

$$
\begin{aligned}
& \text { كز سفيلى تيره شد بىاشتباه } \\
& \text { قلب مغشوش است آن روى سياه }
\end{aligned}
$$


Cehennem ateşi saf olmamaktandir; niceleri kalplerinin saf olmamasından dolayı rüsva olur. “Yüzlerin karardı̆̆ ve ăgardı ̆̆ gün”, her toplulukta saf kalp kendini gösterir. O kara yüz, saf olmayan kalptir; şüphesiz beyazlıktan (sonra) kararmıştır. (b. 126-128)

$$
\text { تا جر نـود آن تيـر مدل ظلمت شكوه آند }
$$

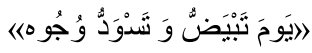

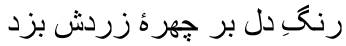

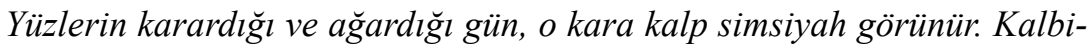
nin rengi, sarl suratına vurur; sarı yüz ondan dolayı karardı. (b. 282-283)

Münkirin gönlündeki bu karalığın sebebi körlüğünden yani doğru yolu inkâr etmesindendir. (b. 274-276, 281) Bununla birlikte Kur'ân'da, Kiyamet Günü Allah’a ancak kalb-i selîm ile gelenlerin fayda bulacağı ayeti yer alır:

“O gün ki, ne malın mülkün, ne de çoluk çocuğun bir yararı olmayacaktır; yalnızca Allah'ın huzuruna kötülükten korunmuş bir kalp [kalb-i selîm] ile çıkanlar (kurtulacaktır)!” (Kur'ân, Şu'arâ 26/88-89) (Esed 2009: 904)

Gülşenî’nin ögütlerinden biri de, zamanı firsat bilip ölmeden önce ölmenin idrakine varabilmektir. Ölmeden önce ölmeyi bilen kimse, iki cihanı da Bir'in nuru ile bir görür ve gönlü bu ilahi nurla aydınlanmış olarak yakîn bilen olur. (b. 129-135)

Salikler için bir diğer önemli husus; Allah'a ulaşma yolunda aczinin farkında olarak dalalete düşmemek için bir rehberin gerekliliğidir. Kimin rehberi yoksa o kişinin yolunu kaybetme ve dalalete düşüp yolsuz kalma tehlikesi bulunur. Gülşenî bunu şu şekilde ifade eder:
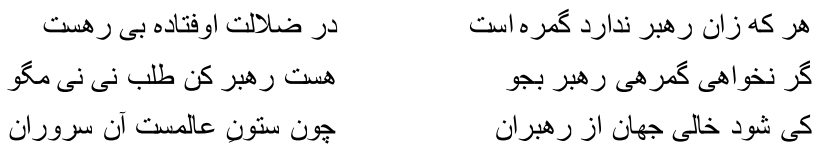

Kimin rehberi yoksa yolunu kaybeder; dalalete düşüp yolsuz kalır. Yolunu kaybetmek istemiyorsan rehber bul; rehber talep et, hayır deme. Cihan rehberlerden nasıl yoksun olur; o serverler âlemin sütunlarıdır. (b. 145-147)

Bu noktada Gülşenî, kendi rehberi ve şeyhi Rûşenî’nin de adını zikreder. Gülşenî’nin, varlık ve yokluk kavramlarına sıklıkla değindiği beyitlerin- 
de kendinden geçtiği hâl ile ayık olduğu vakitlerin birbirinden ayırt edilemez olduğu görülür. Aklı başında iken akılsız/divane oluşunu, kendinde olmama ile kendinde olmanın birlikte var oluşunu, var mı yok mu, hayal mi hakikat mi olduğunu bilemeyişini ifade ederken başındaki mutlak sevdayı tarif eder ve varlığını yokluktan görür. Bu hâl ile hayret içinde olduğunu dile getirir. (b. 155-161) Hayret, "kalbe gelen bir tecelli sebebiyle salikin düşünemez ve muhakeme edemez hâle gelmesi"dir. (Uludăg 2012: 163) Burada Gülşenî, bu hâli tarif ve izah etmekteki acziyetinden de bahseder. Her şeyin beyanının marifet/hakikati bilmekle mümkün olduğunu belirtir.

Mana ve suret, birbirlerinden bağımsız olarak düşünülemeyen iki önemli kavramdır. Gülşenî, manayı idrak etmek için sureti tasavvur etmenin ve müşahedenin etkisine; bu manada suretin gerekliliğine işaret eder. Suret mana için vardır; suretsiz yani nişanesiz varlığın vücud bulması güçtür. Mevlânâ'nın bir sözü bu hususu açıklar nitelikte bir ifade olarak zikredilebilir:

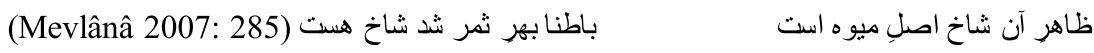

Görünüşte ağacın dalı meyvenin aslıdır. Gerçekte dal meyve için var olmuştur.

Yani suret, manaya (asıl hakikate) ulaşmada gereklidir; bunun dışında ise sureti terk etmek, surete bağlanmamak gerekir. Gülşenî, salike sureti terk ettiği vakit manadan yani hakikatten başka bir şeyin görülmeyeceğini söyler ve bunu

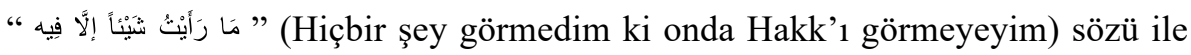
pekiştirir. (b. 182-184) Surete bakıp mananın idrakine varan ve hakikate erişen salik tevhidi bilip kendisini aradan çıkarır, her şeyde Hakk'1 görüp gayrısına kapılmaz ve o vakit fena makamına ulaşır.

Geçici olan suretten vazgeçip kalıcı olan manaya bakmayı ve ona yönelmeyi öğütleyen Gülşenî, surete olan bağın ziyanına ilaveten kin, haset, buğz ve hevadan da uzaklaşmayı nasihat eder; zira bunların sebep olduğu ateşin, cehennem ateşinden de beter olduğunu ifade eder. (b. 202) Kötü huy, kişiyi cehenneme götüren bir şeydir. Kötü huy dışında kişinin imanını tehlikeye sokabilecek bir diğer şey ise gönlünde zan ve şüpheye yer vermesidir. Zan ve şüpheyi gönlünden çıkaran kişinin gönlüne şüphesiz yakîn yerleşir. (b. 203-214) Mümin ve müttaki (dinin emir ve yasaklarına tam olarak uyan, günah ve haramdan sakınan, Allah'tan korkan) olmaya talip olan kimse nefsini dünyevî bağlardan koparıp yakîni seçendir. Kişiyi cehenneme götü- 
recek kötü huylardan biri de hırsl1/açgözlü olmadır. (b. 215-241) Gülşenî bu hususu ifade ederken (Kur 'ân, Kaf 50/30) “هَّْ مِنْ مَزيد " (Hel min mezîd: Daha yok mu?) ayetine iktibas yapar. (b. 242) Hırslı bir insan, kendisine ne kadar çok şey verilse bile her seferinde 'Daha yok mu?' der. Cehennem ehlinden olmak istemeyen, hirs ve emelden vazgeçmelidir. Gülşenî, cimriliğin de cehennemlik olacağına dair bir hadîs-i şerîfe (Bkz. Canan 1988: 69; Beyhakî 1990: 428, 435) iktibas ile cimriliği cehenneme tuzak ve cehenneme atılmış bir tohum olarak ifade eder. (b. 243-245)

Kişi bu dünyada ne ekerse alacağı karşılığı da ona layık ve ona denk olacaktır. Bu yüzden ölü toprağa sahip olmamak için bu dünyada kötü ve çirkin tohum ekmemelidir. (b. 245-251) Bu manada dünya bunun için bir firsattır ve firsatı ganimet bilip onu ele geçirmeye çabalamak, bugünün işini yarına bırakmamak akıllıların işidir; fursatı kaçırmak ise ahmaklık olur. (b. 252-263) Gülşenî “ölmeden önce ölünüz” hadisine burada da vurgu yapar. Zira yarın bugünden belli olur; kişiye bugünü yarın olur. (b. 265-266) Nitekim Peygamber Efendimiz, "Dünya ahiretin tarlasıdır. Herkes burada ne ekerse ahirette onu biçer" (Aclûnî 1351: 412) buyurmuştur.

Gülşenî, insanın kalbini/gönlünü Allah'ın mazharı olarak tanımlarken 'ayna' metaforuna yer verir. Peygamberlerin ve velilerin gönülleri Hakk'ın nuru ile safidir ve bu parlak aynaya nispet edilir. Hak katında ister iyi ister çirkin ister said (iyiliği, üstün ahlakı sebebiyle makbul olan kimse) ister şaki (makbul olmayan kimse) olsun herkesin gönül aynası yüzüne yansır ve o aynada herkes kendisini görür. (b. 284290) Gülşenî, gönlü ilahın nuru ile nurlanmış kimsenin mutlak hakikate yani yakîne

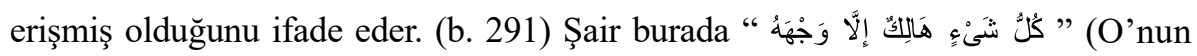
zatından başka her şey yok olacaktır) (Kur'ân, Kasas 28/88) ayetine iktibas ile Allah'tan başka her şeyin faniliğini vurgular ve bunu idrak edebilmenin tek yolu olarak benlikten kurtulmayı gösterir. (b. 297-301)

Gülşenî his gözü ve his kulağının, kendi beyanını anlayabilmede kör ve sağır olduğunu, marifetin idrakinin ancak kalp gözü ve akıl kulağı ile mümkün olabileceğini ifade etmişti. Aynı zamanda ilahi sırların idrakinin keşf ile olacağ1nı vurgulamaktadır. (b. 300-308) “ "لَاعَيْنْ رَأَتْ أُدْنْ سَمِع (Görecek göz işitecek kulak yoktur) remzi ile "(Seni yalanlayanlar) hiç yeryüzünde dolaşmadılar mı? Zira dolaşsalardı elbette düşünecek kalpleri ve işitecek kulakları olurdu. Ama gerçek şu ki, gözler kör olmaz; lâkin göğ̈̈sler içindeki kalpler kör olur." (Kur 'ân, Hac 22/46) ayetine iktibas yapılır. (b. 303) İyilerden/ahlakı güzel kimselerden 
olmayı öğütleyen Gülşenî, bu kimselerin kimler olduğunun Kur'an'da bildirilmiş olduğuna şu ayete iktibas ile işaret eder: "İyilik, yüzlerinizi doğu ve batı tarafina çevirmeniz değildir. Asıl iyilik, o kimsenin yaptığıdır ki Allah'a, ahiret gününe, meleklere, kitaplara, peygamberlere inanır. (Allah'ın rızasını gözeterek) yakınlara, yetimlere, yoksullara, yolda kalmışlara, dilenenlere ve kölelere sevdiği maldan harcar, namaz kılar, zekât verir. Antlaşma yaptığı zaman sözlerini yerine getirir. Sikıntı, hastalık ve savaş zamanlarında sabreder. İşte doğru olanlar, bu vasıfları taşıyanlardır. Müttakîler ancak onlardır!" (Kur'ân, Bakara 2/177) (b. 310-311)

Gülşenî’nin ifadesine göre ayette zikri geçen iyi kimselerden olmak isteyen kişi, nurdan azık yapıp gönlünü onunla beslemeli ve iyilik tohumu yetiştirmelidir. (b. 312-314) Gülşenî, işiten kulak bulduğu takdirde bu manevi gida ile besleyip tazelediği beyanından başka söz söylemeyeceğini belirterek manzumeyi tamamlar.

\subsection{Tenkitli Neşri}

Hazırladığımız manzumenin, Gülşenî’nin Farsça Divan'ı içinde yer aldığından yukarıda bahsetmiştik. Farsça Divan'ın tespit edebildiğimiz nüshaları şöyledir:

a) Süleymaniye Kütüphanesi, Fatih Bölümü’nde 3866 numarada kayıtl1dır. 250x160-175x80 cm ölçülerindedir. 505 varaktan ibaret olan eserde satır sayısı 17-18'dir. Talik yazı ile yazılmıştır. İlk çift sayfa tezhiplidir. Cildi kırmızı, içi ve dışı yaldızlı, soğuk damgalı, mıklepli, şemseli, köşebendlidir. Hamza b. Abdullah tarafindan 931/1525 tarihinde Kahire'de istinsah edilmiştir.

b) Millet Kütüphanesi, Farsça Eserler 418 numara kayıtlı olan nüsha 286x185-230x140 cm ölçülerindedir. 265 varaktır. Cildinin arkası yeşil bir deriyle tamir görmüştür. Mıklepli, şemseli, kahverengi meşin cilttir. Talik hattı ile yazılmışıtır. Başlık müzeyyen ve cetvelleri yaldız müzehhebdir. İstinsah tarihi ve müstensihi belli değildir.

c) Ankara Üniversitesi Dil, Tarih ve Coğrafya Fakültesi Kütüphanesi 1235 numarada kayıtlı olan bu nüsha 205x132 cm ölçüsündedir. Mıklepli, şemseli, zincirekli, kahverengi meşin ciltlidir. 535 varaktır. Her sayfada 16 satır vardır. Talik hattı ile yazılmıştır. Cetveller kırmızı, başlık müzeyyendir. Başında “Dîvân-ı Kutbü'l-Ârifin ve Sultanü'l-Muhakkıkîn Hazret-i 
Gülşenî Nevverallâhü Merkadehü’ ibaresi yer almaktadır. İstinsah tarihi ve müstensihi belli değildir.

d) Süleymaniye Kütüphanesi Halet Efendi Bölümü’nde 272 numarada kayıtlı Ma'nevî adlı eserin içerisinde $382^{\mathrm{a}}-486^{\mathrm{b}}$ varakları arasında yer alan nüshada Farsça Divan'dan gazeller, rubailer, kıtalar ve mesneviden oluşan bir müntahabat bulunmaktadır.

e) Kahire Kütüphanesi'nde üç adet nüsha daha bulunmaktadır. Buradaki nüshaların bilgileri ise şu şekildedir:

İbrahim b. Muhammed b. İbrahim b. Şehâbeddîn Abdoğmuş Edrî, Divan-1 Gülşenî, İbrahim b. Muhammed b. İbrahim Gülşenî adıyla kayıtlı olan bu nüsha $12 \times 20.5 \mathrm{~cm}$ ölçülerinde olup her sayfada 17 satır vardır. 440 varaktan ibarettir. Müstensihi ve istinsah tarihi belli değildir.

İbrahim b. Muhammed b. İbrahim b. Şehâbeddîn Abdoğmuş Edrî, Divan-1 Gülşenî/Hazret-i Rûşenî, İbrahim Gülşenî adıyla kayıtlı olan bu nüsha 537 varaktan ibarettir. $15.5 \times 22 \mathrm{~cm}$ ölçülerinde olup her sayfada 15 satır vardır. Müstensihi ve istinsah tarihi belli değildir.

İbrahim b. Muhammed b. İbrahim b. Şehâbeddîn Abdoğmuş Edrî, Divan-1 Gülşenî, İbrahim b. Muhammed b. İbrahim adıyla kayıtlı olan bu nüsha, $20.5 \times 31 \mathrm{~cm}$ ölçülerindedir. 411 varaktan ibaret olup her sayfada 11 satır vardır.

Müstensihi ve istinsah tarihi belli değildir. (İhvan 1380: 104)

Kahire'de bulunan nüshaları temin edemediğimiz için tarafımızdan hazırlanan bu manzumenin tenkitli neşri oluşturulurken dört nüshadan faydalanılmıştır.

Bunlardan esas aldığımız nüsha müellif zamanında istinsah edilen ve diğer üç nüshadan daha doğru olduğuna kanaat getirdiğimiz Süleymaniye Kütüphanesi'nde bulunan nüshadır. Aşağıda sunduğumuz bu manzume Süleymaniye Kütüphanesi (Fatih Bölümü) nüshasında (S) 496 ${ }^{\mathrm{b}}-505^{\mathrm{a}}$ varaklar1 arasında ve Millet Kütüphanesi nüshasında (M) $257^{\mathrm{b}}-265^{\mathrm{b}}$ varakları arasında divanın sonunda; Süleymaniye Kütüphanesi (Halet Efendi) nüshasında (H) 382a -385 varakları arasında ' مثنوى ' (mesnevi) başlı̆̆gyla ve Ankara Üniversitesi Dil, Tarih ve Coğrafya Fakültesi Kütüphanesi nüshasında (A) ise $1^{\mathrm{b}}-15^{\mathrm{b}}$ varakları arasında ' التوحيد ' (el-tevhîd) başlığı ile divanın başında yer almaktadır. Beyitlerin sol kenarında nüshaların varak numaraları, sağ kenarında müteselsil beyit numaraları verilmiş olup nüsha farkları dipnotta gösterilmiştir. 
$\mathrm{M} 257^{\mathrm{b}}$

$\mathrm{S} 496^{\mathrm{b}}$

$\mathrm{A} 1^{\mathrm{b}}$

$\mathrm{H} 382^{\mathrm{a}}$

$\mathrm{S} 497^{\mathrm{a}}$

$\mathrm{A} 2^{\mathrm{a}}$

$\mathrm{M} 258^{\mathrm{a}}$

$\mathrm{A} 2^{\mathrm{b}}$
جهه سود از ذكر و فكر و خواندن اسما6

اكر نعشايِى از دل عقدِ دنيا

نتيجه جز كرهاز وى جه زايد

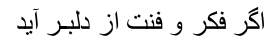

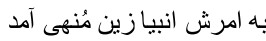

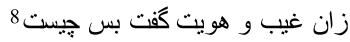
ز غيب آن غيب شد 10 مشكل ز زئ مغلق

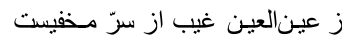

بود دركش ز ادر اكات بيرون 12 ندارد از مذاقش دركِ درّ اك 14

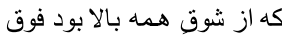

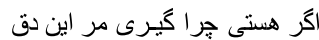

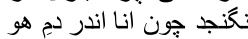

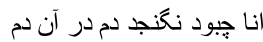

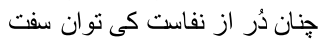
ز مكتومى نشد هركز هويدا ز بكرى كس ورا هركز نسفته ند هئه

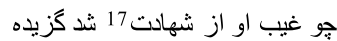
نه بالا ديده است او او رانه 18 زير زيرى

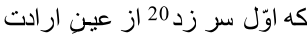

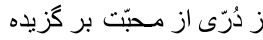

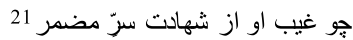

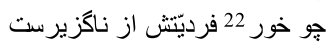

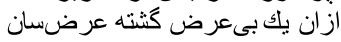

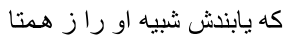
ز كنهش عقلِ كل هم بيىنبرده ازو جز كف نشد دركِ خردها
جو ذكر و فكر تو عقده فزايد

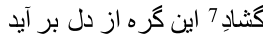

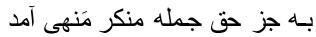

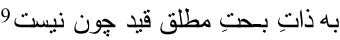

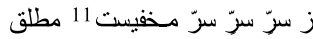

ز اسما و مسمّا بحت ونس و صافيست

ز عين غين او 13 جون هست بهن بيجون

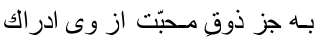
10

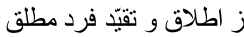
جو منصور از انانيارى فردى دمى نو انا از هستي منصور شد دم

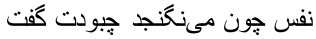

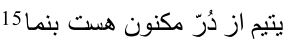

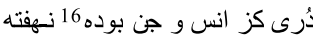

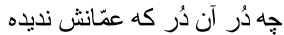

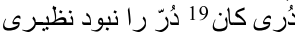
دُر درياى غيبى بـشهان

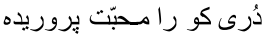
20

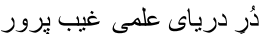

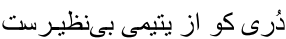

ز ذُر آنجه بود يِيدا و بنهان

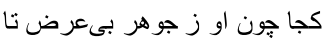

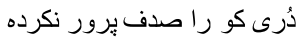

6 ذكر و فكر و خو اندن اسما A: ذكر و فكرت خواندن اسما M، H: ذكر فكرت خو اندن S

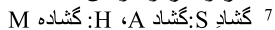

8

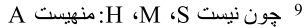
10

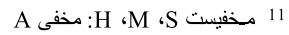

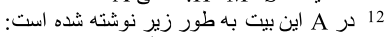

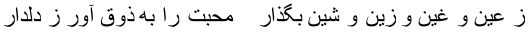

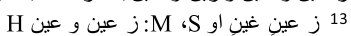
14

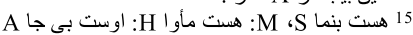

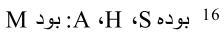

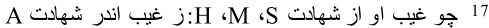

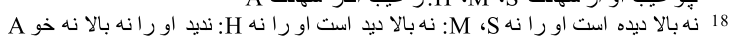

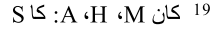

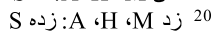

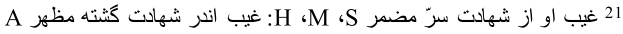

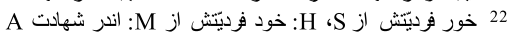


$\mathrm{S} 497^{\mathrm{b}}$

$\mathrm{A}^{\mathrm{a}}$

M258

$\mathrm{A} 3^{\mathrm{b}}$

$\mathrm{H} 382^{\mathrm{b}}$

$\mathrm{S} 498^{\mathrm{a}}$

$\mathrm{M} 259^{\mathrm{a}}$

$\mathrm{A}^{\mathrm{a}}$

$$
\text { كزو درياى } 23 \text { حكمت شد جو قطره }
$$

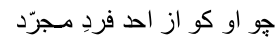
احد را بىاحد از وى شهودست إن فردّ بيان از وى نباشد جز كه مشهود 25

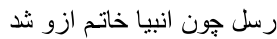

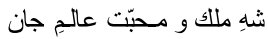

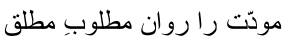

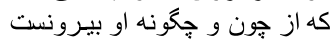
ز 28 سّر عشق مطلق عين اعبان

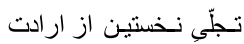

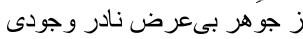

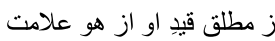

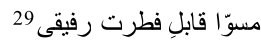

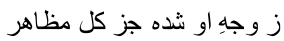

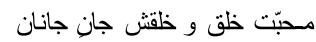
نه خاك و باد و آب و آتش و مان 30

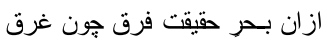

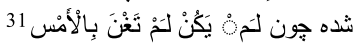

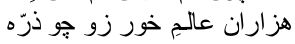
مرباءٍ ابد از حكمِ تقدير

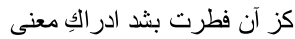

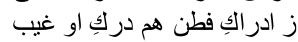

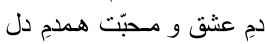

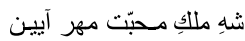
يرى رخسار بـهنر از قمر 33 جهر جهه جسم آن جان بدن نه اين نه آن آن است

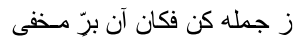
جو طمسست به جز كل كل قل و قمعش 35

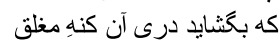
به ملكِ حسن ازو شاهِ صباحت

$$
\text { ز قدرت كو جو او نادر ز فطره }
$$

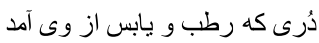
دُرى كو جون رُون صمد مطلق وجودست

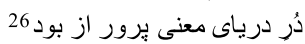

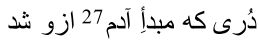
قيامتكاهِ عشق و آدمِ جان

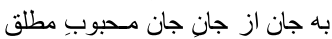

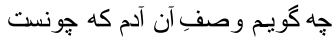

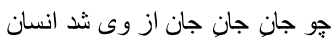

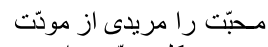
ز جز و كل مودّت را ودودى مودى

ز ظاهر باطن او جز كل تمامت ودى ردى

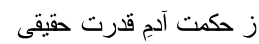
ز حسنا احسنييش كثته ظـاهر به ظاهر آدمِ باطن ز جان آن جنان

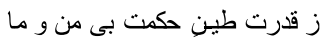

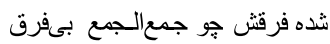

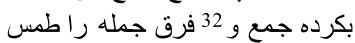

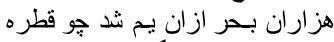

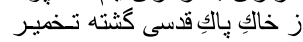

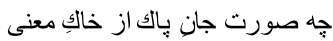

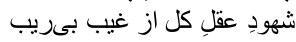

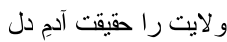

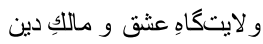
50

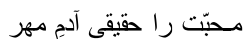

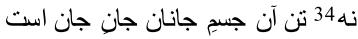

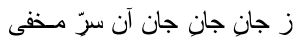

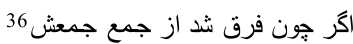
بود تشبيهِ او تنزيه مطلق في في 55 به يو سف جهره از وى شد 37 ملاحث

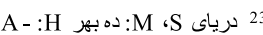
24

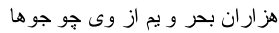

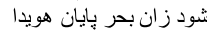

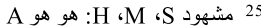

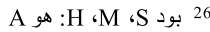
M 27 $\mathrm{H}$ ه : : A ، $\mathrm{M}$ ،S j 28

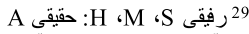
S 30

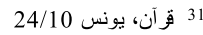
$\mathrm{M}-: \mathrm{A}$ ،H ، $\mathrm{S}, 32$

33

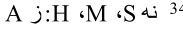

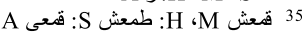

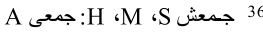

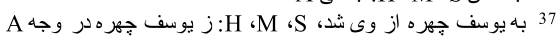


ز خود مشهودِ قدرت بىشك و ريب

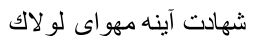

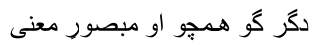

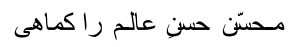

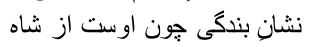

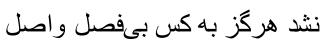

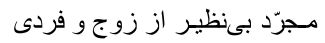

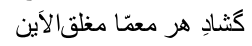

$\mathrm{S} 498^{\mathrm{b}}$ $\mathrm{A} 4^{\mathrm{b}}$

$\mathrm{M} 259^{\mathrm{b}}$

$\mathrm{A}^{\mathrm{a}}$

S499a

$\mathrm{A} 5^{\mathrm{b}}$
بيخود از خود 40 با خودى بيوستيم

كوش هوش آور شنو سر اي بسر

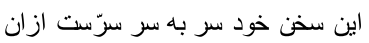

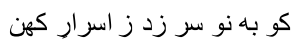

مست و هشيارى در آنم بيخبر

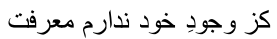

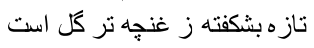

بىنظيرى همجو او جون خور 42 فريد

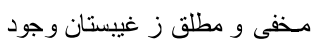
هست قلب مؤمن آن بيت العنيق

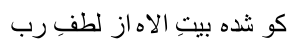

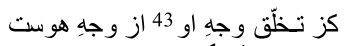

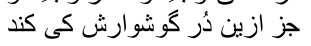

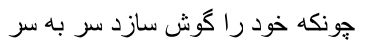
هوش كشته يابد از هش آكهى

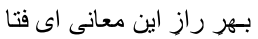

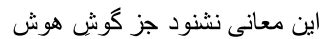

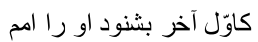

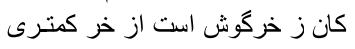

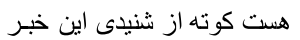

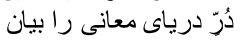

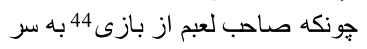

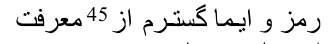

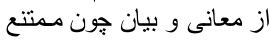
شاه و بيدث فرز ازان 46 ديده شود دئ منكرم تامات كردد روى زئ زئ
عزيز مصر عزّت شاهدِ غيب

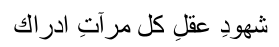

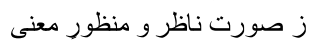

ز فطرث كشته او صبغ 38 الهـى

مبدّل كى شود آن صبغة الله

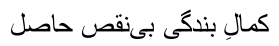

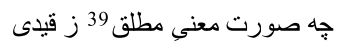
مقيّ نسبتى از مطلث العين

يادم آمد بعدِ صدو از مستيم 65

فرق و جمعم دادن از وحت دكر

نشنود اين كوش حس اسرار جان

سرّ غيبست از شهادت اين سخن اين

بو العجب صحوى ز مستييم 41 بتر

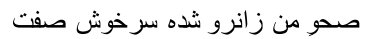

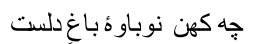

كوش كس نشنيده جُشَ كُش هم نديد

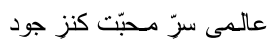

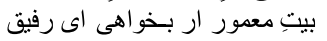

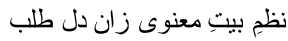

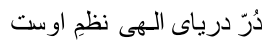

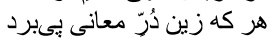

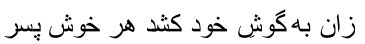

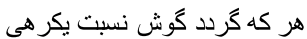

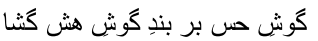

كوش حس كر نسبت است از اين نيوش

كوش حس را حث ازين رو كفت اصم

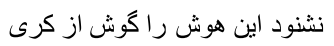

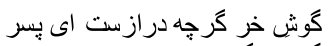

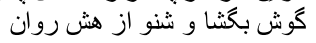

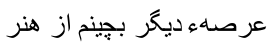

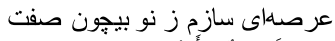

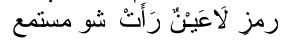

نرد و شطرنجم به سر جيده شود

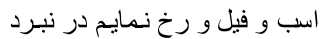

90

A ،H ، M M 38

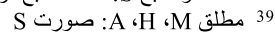

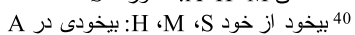

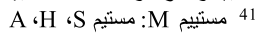

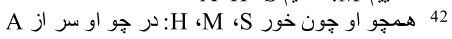

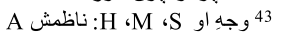
Sبازي 44

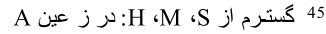
46 
M $260^{\mathrm{a}}$

H383a

$\mathrm{A}^{\mathrm{a}}$

$\mathrm{S} 499^{\mathrm{b}}$

$\mathrm{A} 6^{\mathrm{b}}$

$\mathrm{M} 260^{\mathrm{b}}$

A $7^{\mathrm{a}}$

$\mathrm{S} 500^{\mathrm{a}}$
طاقتى كو در جهان آن حمله را

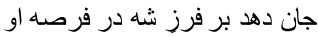

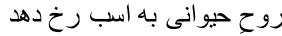
تا بداند لعب نردى جإكباز

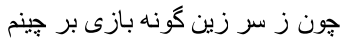

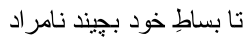
كه ز عرفان كل شده از وى لسان

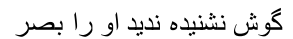

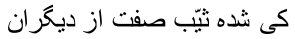
نظم كردهست ور ان نيك و 49 خسى كى به درّ ديكران او بيزيرو است

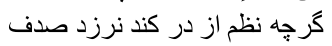

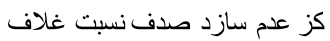
دُر بود نادر ز درياز قدم صدم

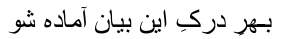
كى بفهمى تو ازين معنى بيان كى ز حالِ نيستان يابى خبـر

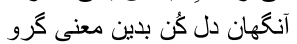

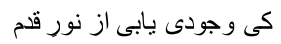

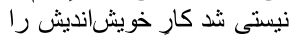

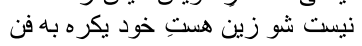

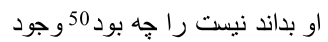

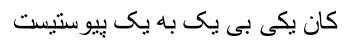

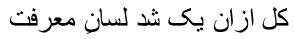

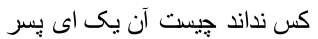
كز يقين يكى دران او بىشكست جيت

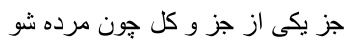
كى شوى آكه صفت از يونكى ئك جري كر بـخو اهى زان يكى بـ بس كمرهى

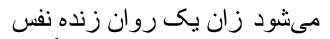

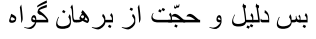
بـهر نطق حق زبان آماده كن بردي

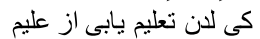

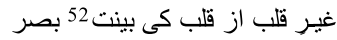

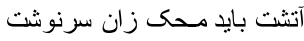
اي بسا قلبى كزو رسوا شود قلب صافِ خود 53 نمايد هر كرو نمون
برد بنمايم ز حق آن جمله 47 راب بري

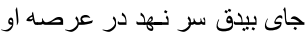

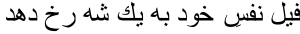

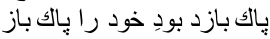

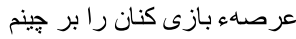
سازد او بازي بازنده كثاد

هست ايما از معانى اين بيان

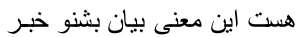

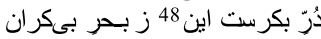

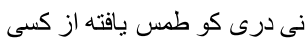

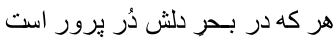

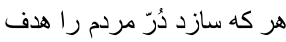

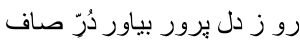

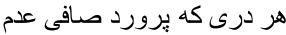

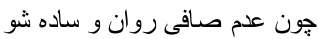

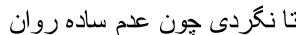

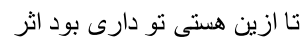

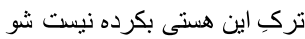

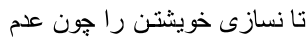
110

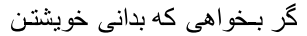
هر كه زين هستث شود جون نيست به بود حيرتِ جز كل ز نيستى هستيست هنت

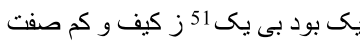

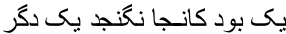

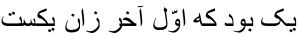

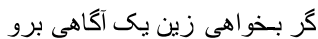

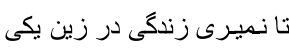

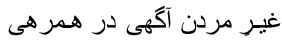

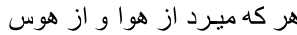

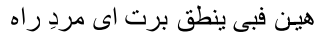

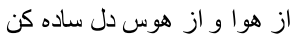
تان نكردى صداف قلب و ول دل سليم هون ندارى قلب صافى از كدر

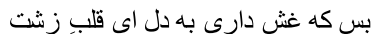

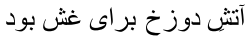

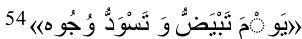

47 برد بنمايم ز حق آن جمله S، بر ، برد باثد مات حق در جمله A

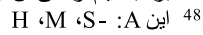

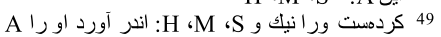
50

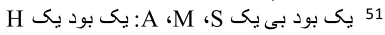

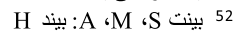
A 53

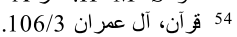




\begin{tabular}{|c|c|c|c|}
\hline & 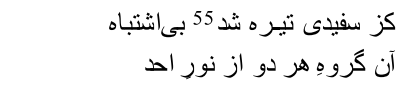 & 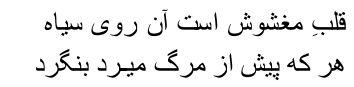 & \\
\hline M261 & از يقين او بىگمان داننده شد & هر كه از نور احـ بيننده شد & 130 \\
\hline \multirow[t]{9}{*}{$\mathrm{A} 7^{\mathrm{b}}$} & 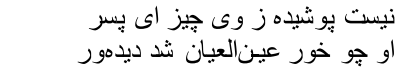 & هر كه زان نورست ريش روشن ديدهر & \\
\hline & همجو خور از روشنى 56 در داور اوست & روشني مرددِ ديدهور اوست & \\
\hline & كز ضياروشن ز نور كبرياست & روشنى را روشنى ده زان ضياست & \\
\hline & آن ضيا سازد سراسر اى يّر & مردجِ روشندلان را جون بصر & 135 \\
\hline & بينش آن ديده را آماده شو & روز نور الله سراسر ديده شو & \\
\hline & كان ز نور الله بود بكزيده ديد 57 & روشنى را كلشنى زان ديده ديد & \\
\hline & جز يكى كى بيند او هر دو سرا & هر كه زان بينش كثايد جشم را & \\
\hline & جون ز يكّست يقينش بىشكى & كى جو احول دو ببيند از يكى & \\
\hline & زان دو بيندارد اكر بيند احد & جشبِ حس احول صفت يك ننكرد & 140 \\
\hline $\mathrm{S} 500^{\mathrm{b}}$ & كور بودن بـهتر ازانت نظر & جونكه تو يك را دو بينى زان بصر & \\
\hline $\mathrm{A}^{\mathrm{a}}$ & تا جو او عينالعيان كردى جلى & جشم بحشا جون خور از روشن دلى & \\
\hline \multirow[t]{6}{*}{$\mathrm{H} 383^{\mathrm{b}}$} & رهنما شد او جو خور روشن بصر & هر كه جون خور از ضيا شد ديدهور & \\
\hline & كو ز مه روشن دلست از نور رب & رو جو خور يك ديدهور رهبر طلب & \\
\hline & در ضلالت اوفتاده 58 بىر هست & هر كه زان رهبر ندارد كمره است & 145 \\
\hline & هست رهبر كن طلب نى نى مكو & كر نـخواهى كمرهى رهبر بـجو & \\
\hline & جون ستون عالمست آن سروران & كى شود خالى جهان از رهبران & \\
\hline & بىتـرّك ساكن و هم 59 سايرند & نقطهء بِركار دور دايرند & \\
\hline \multirow[t]{4}{*}{ M261 } & كز مـحبّت رو نـما شد بس ودود & كس نداند سرّ آن نقطه وجود & \\
\hline & كس نداند جز كه 》» الصنَّدَدي 60 & سرّ آن نقطه بـه جز فرد و احد & 150 \\
\hline & جز احد كو بىدو يك شد 61 واجدى & كى بداند آن احد62 را واحىى & \\
\hline & كى بداند از مقيّ فرد احد & آن احد كه مطلقست از هر احد & \\
\hline \multirow[t]{7}{*}{$\mathrm{A} 8^{\mathrm{b}}$} & بس كه مطلق شد ز قيدٍ هر احد & آن احد را كفو كى كردد احد & \\
\hline & كى شود كفوش احد از جمع فرد & هر احذ كز جمع جمعست اى ولا & \\
\hline & كرد جون ديو انهام زين ماجرا & اى دريغا هوش بيهوشى مرا & 155 \\
\hline & بيخودى در با خودم بييدا نهان & بو العجب ديوانهام بـخرد دران & \\
\hline & حيرت اندر حيرتم كه جيستم & اين عجب نه هستم و نه نيستم & \\
\hline & خود به خود سازم بيان از معرفت & همجِ سودايى ازين واله صفت & \\
\hline & نيستى در هست نسبت آمده & زان ندانم من جيم بىمن شده & \\
\hline \multirow[t]{4}{*}{$\mathrm{S} 501^{\mathrm{a}}$} & جون ندانم هست و يا خود نيستم & من خيالم يا حقيقت حيستم & 160 \\
\hline & بس كه سوداى سرم شد زو 63 مآل & زان جو لا ادريّه كثتتم زين خيال & \\
\hline & زان ز مدرك عجز لا احصى ثناست & دركِ او ادراك را حيرتفزاست & \\
\hline & كس جه گويد كيف ازان نادر شهود & بس كه بيكيفست از كيف آن وجود & \\
\hline $\mathrm{A}^{\mathrm{a}}$ & كل ازان شد بس زبان معرفت & جون نيايد كيف وصفش در صفت & \\
\hline
\end{tabular}

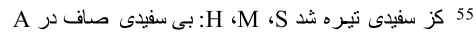

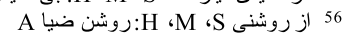

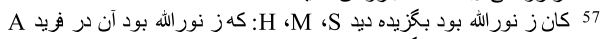

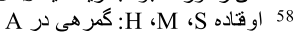

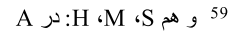
60 قُ آن، الاخلاص

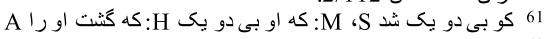
62

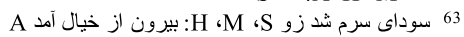


A $9^{\mathrm{b}}$

$\mathrm{A} 10^{\mathrm{a}}$

$\mathrm{M} 262^{\mathrm{b}}$

$\mathrm{H} 384^{\mathrm{a}}$

$\mathrm{A} 10^{\mathrm{b}}$
همجو ذاتش كشته بيكيفش صفات كس جه تاند 64 كفت از ناد نادر شهود نسبث از وى قدرت آسا حكمت است أنت

M262 ${ }^{\mathrm{a}}$

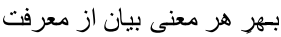
بىنسب كى وصف ازو 65 باهر شود برد جز و كل اندر كسى را معرفت اوّل آخر اي فتا تم الكلام

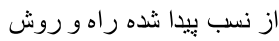
اوّل آخر جنبش كل 66 كاينات

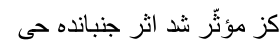

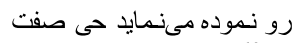

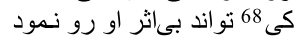
بهري معنى صورت آينده شود بـهر خود آرد برد او دم بلدم

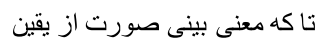

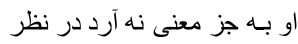

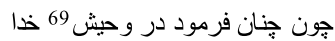
بس برين معنى ز حق بـ بـ اشتباه

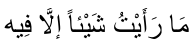
صورث معنى بديد اندر نظر

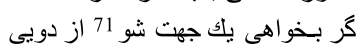
صورت از وى حكمت قدرت بوت بود 72

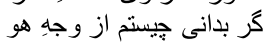

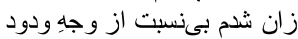
شو معبّر بـهر آنك آيد رود 74 نا كه جز معنى نبينى از صور نى جو صورت معني 75 لايعنى شد إند زان جدا از معنى لايعنى شود هودي

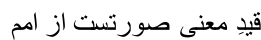

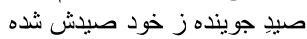

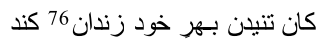

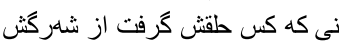
برد سجّين برش ز زانش كزند 78

$$
\begin{aligned}
& 165
\end{aligned}
$$

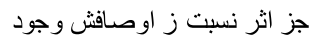

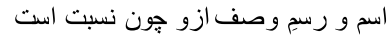

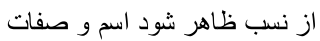

$$
\begin{aligned}
& \text { ذاتِ وصفى از نسب ظاهر شود نود }
\end{aligned}
$$

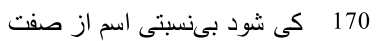

$$
\begin{aligned}
& \text { از نسب ظاهر شود منزل مقام }
\end{aligned}
$$

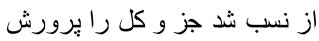

$$
\begin{aligned}
& \text { از نسب بيدا شود اين ممكنات }
\end{aligned}
$$

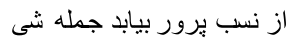

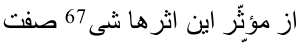

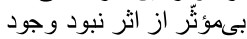

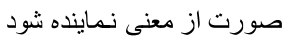

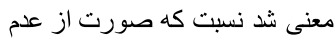

$$
\begin{aligned}
& \text { تركِ صورت كرده كن معنى كزين ندين }
\end{aligned}
$$

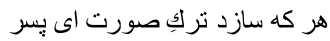

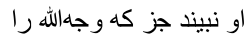

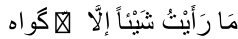

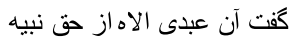

$$
\begin{aligned}
& \text { بس كه بد برهيده او از اين صور الاه از هور نيه }
\end{aligned}
$$

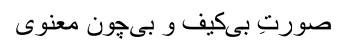

$$
\begin{aligned}
& \text { آن نه صورت معني صورت بورد بون معند } \\
& \text { هن ندانم نيستم يا هست كوري }
\end{aligned}
$$

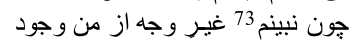

$$
\begin{aligned}
& \text { صورث از معنى جو تعبيرى بود } \\
& 190
\end{aligned}
$$

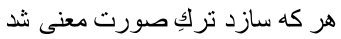

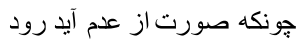

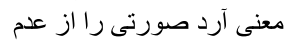

$$
\begin{aligned}
& \text { اهلِ صورت بندِ بىقيدش شده }
\end{aligned}
$$

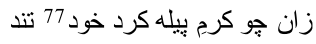

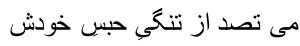

$$
\begin{aligned}
& \text { هر كه داد آخر نفس زان قيدي حئ و بند }
\end{aligned}
$$

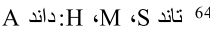

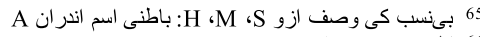
A اند 66

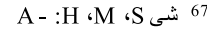
$\mathrm{A} ه: \mathrm{H}$ ،M $، \mathrm{~S}$ S 68

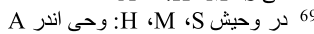

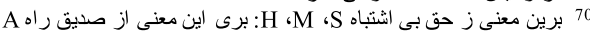

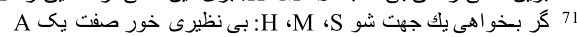

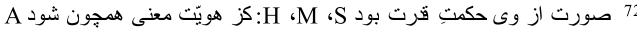

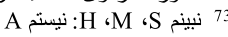

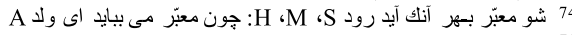

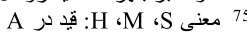

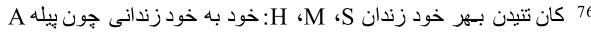

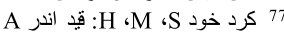


$\mathrm{S} 502^{\mathrm{a}}$

M263a

A1 $1^{\text {a }}$

$\mathrm{S} 502^{\mathrm{b}}$

$\mathrm{A} 11^{\mathrm{b}}$

M263
از 79 عذابش جاودان آن 80 بس ز هنى 81

بودنش منسوس كردد در سقر 82

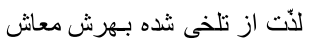

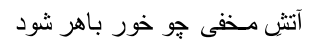
سوزد او را بذتر از نار لظى خور باهي

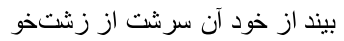
آن ز دوزخ زشتثر بر خود أن

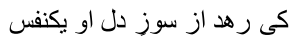

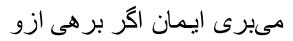

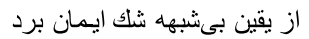
كى برى از ظن ز شكّت بيـروى 85

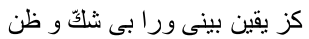

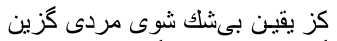
كر دهد جان تو معَ ايمان برد برد

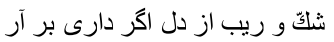
بس بيقن بىشك به دل او بر نشاند

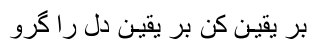

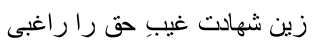
كو جو او در دو جهان نادر وجود

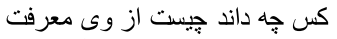
جز كل از قيدش رهيد ديد مطلقى

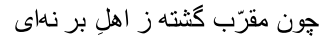

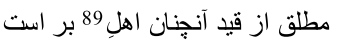

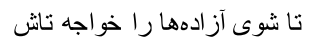

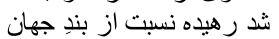
كشته بينم بس حقير از ناكزير

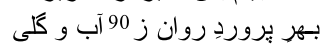

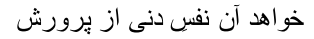

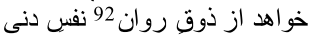
كسنه نسبت باز 93 كردد طعمده جو رون كرجه جز كل آرزويش مىخورد
دوزخ جانش شود آن حبس تنى قيد جون معقول سجنست ایى بهر

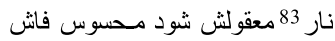

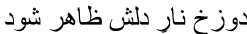

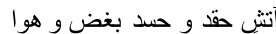

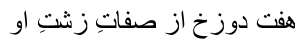
ز آتش زشتي خود سوزد مقيم

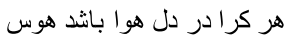
205

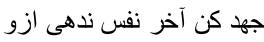

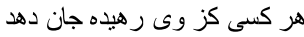

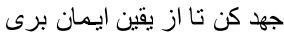

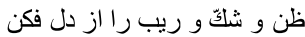
210 هر كر ا868 در دل يقين از ظن دورن بود كر يقين را طالبى ظنتّ كذار

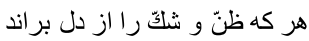

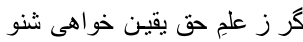

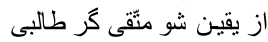

متّىى را غيب بايد شد نمود 87

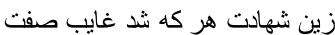
متّقى شو تا بيابى منّقى

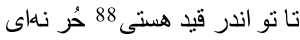

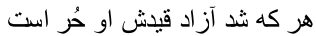

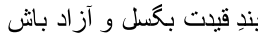

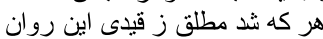

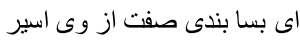

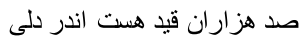

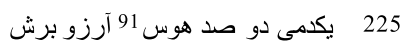

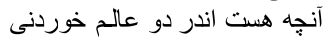

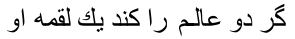
كى جنان نفس دنى سيرى شود راك

78 اين بيت در A به طور زير نوشته شده است:

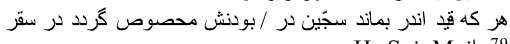
$\mathrm{H}$ ، $\mathrm{S}$ j:M j 79 M - :H S S 80 81 82 S بار 83 84

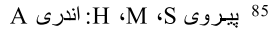
86

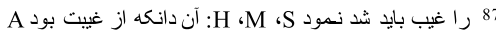

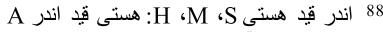

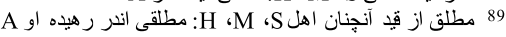

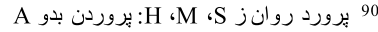

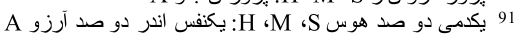


$\mathrm{A} 12^{\mathrm{a}}$

$\mathrm{S} 503^{\mathrm{a}}$

$\mathrm{A} 12^{\mathrm{b}}$

$\mathrm{H} 384^{\mathrm{b}}$

$\mathrm{M} 264^{\mathrm{a}}$

$\mathrm{A} 13^{\mathrm{a}}$

$\mathrm{S} 503^{\mathrm{b}}$
زان جهنّم نسبت او خواهد مزيد كى شود سير از امل كثنته زبون

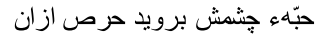

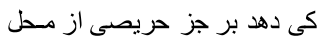
از امل حرصى بود جل 95 در انتظار ازئ

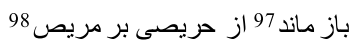
كى شود ساييدهز زو جشيمِ جنان

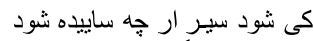

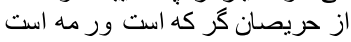

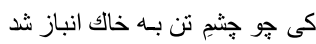

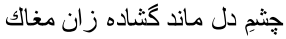

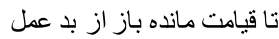

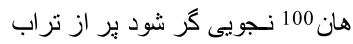

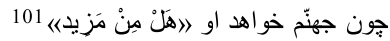
بكذر از حرص جو امل ز امر جليل 102 دوزخى را دانهء دام زان 104 فخ است

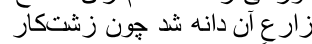

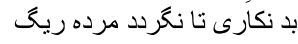
هـجو مردِ زشتِ بدخو نابكار

برخورى حاصل شده كشتست ازان كى ازو جيند كلى آن بيخرد

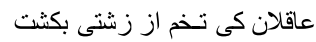
تخمِ نيكى كشت كن اى خوش منش جاهل و كودن غبى زان خر به است كو نداند جيست اقبالش زرد 106

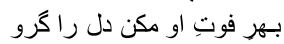
آن قبول از مقبلان زشت و و رد ردست

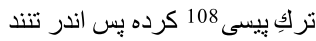

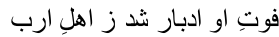

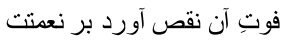

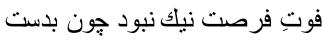

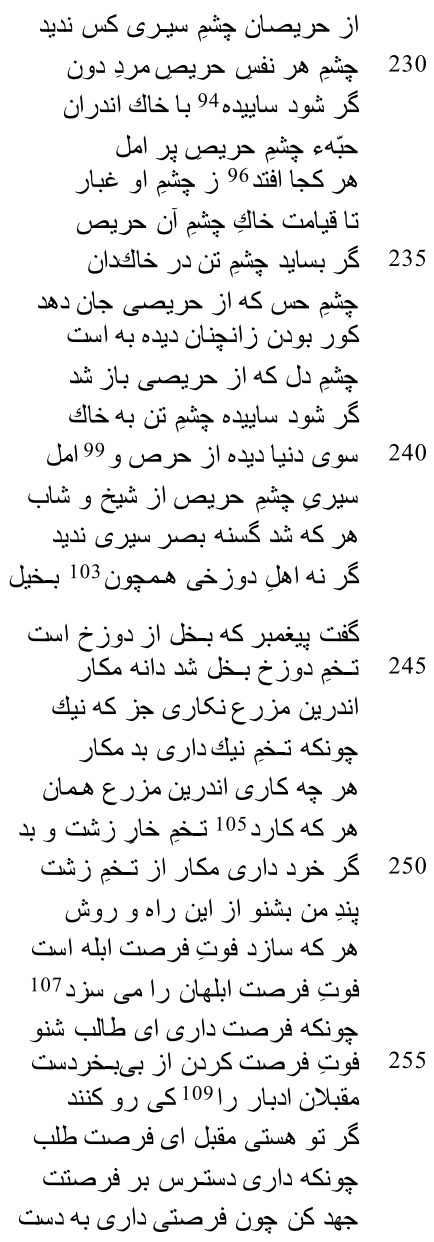

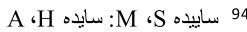

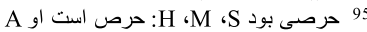

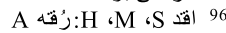

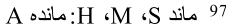

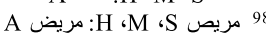

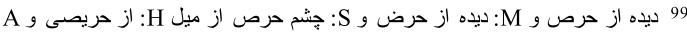
A بر:H ، : 100 101 100 A ماه 102 A همج 103

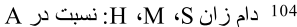

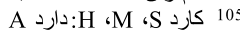

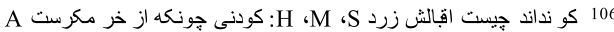

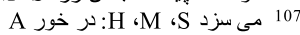

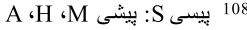

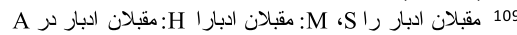


M264 ${ }^{\mathrm{b}}$

$\mathrm{A} 13^{\mathrm{b}}$

$\mathrm{S} 504^{\mathrm{a}}$

$\mathrm{A} 14^{\mathrm{a}}$

$\mathrm{M} 265^{\mathrm{a}}$

$\mathrm{A} 14^{\mathrm{b}}$

$\mathrm{S} 504^{\mathrm{b}}$

$\mathrm{H} 385^{\mathrm{a}}$
جز تغابن نيست از وى دسترس

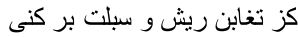

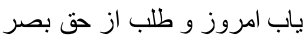
نقدِ فردا بينى امروز ايى فتا

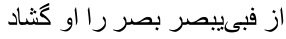
بـهر آن مركى بكن جدّ و شتاب

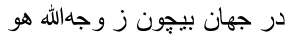
كز يقين برهى ز زنّ ون و التباس

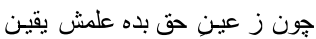
كرد اشارت اصبعين از معرفت

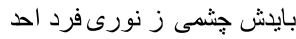
كز قيامت حشر بينى در نظر كى رهى از ظلمت تير فير سرا مىشود اندر دلِ مردِ عنيد كز عمى انكار سازد بر رشد أند دئ كشته بدتر ز اكمه و أكار اعمى ضر ضرير كز شقاوت منكر مردِ ولى بـت بيىسعادت هست جز كل اشقيا

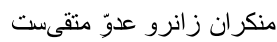

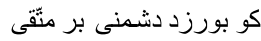
هست منكر بر وليّ عبدي هو دوني

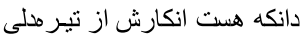

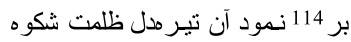

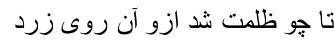

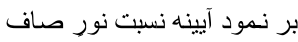

وز كنشت ايشان وجودِ اوليا داشتند از نور حق صافئ ايثنان وحلى اوليا كر شقى باشد و كر 116 باشد سعيد بر نـمايد روبرو جون بون خور عيان هست بيكيف از همه 117 بيجون حون صفات

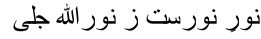
در يقين آن كس بود بى نى نشتباه

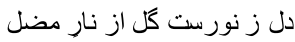
كى ز مسّ نار بينى نور نور نور نار مدر تاز نور نور كردد دل ثرا

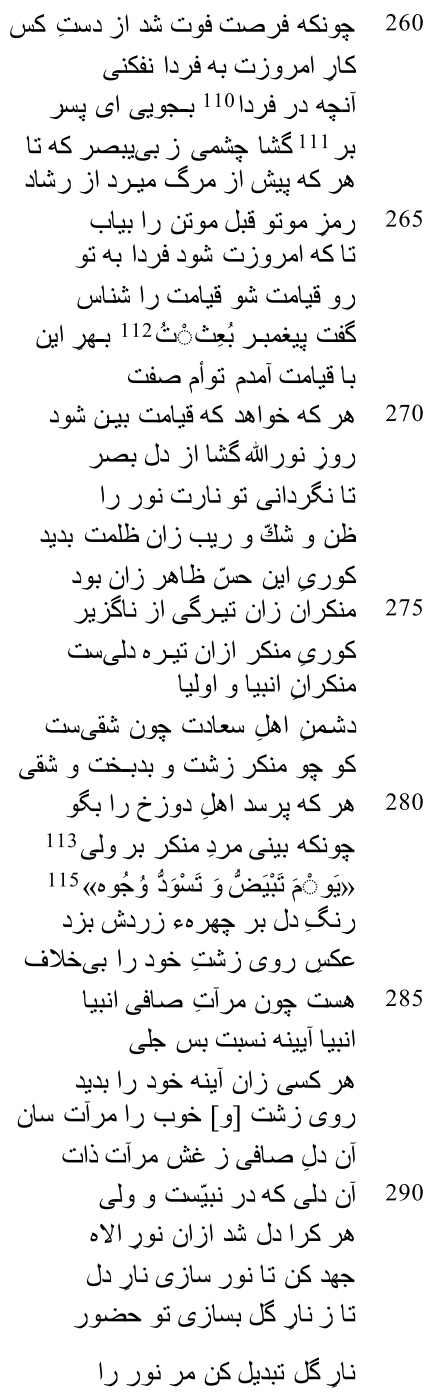

Bkz. Ebû Abdullah Ahmed b. Muhammed b. Hanbel (1999), Müsned, thk. Şu'ayb el-Arnaût vd., Beyrut: 112 Müessesetu'r-Risâle, XXII, s. 320, Hadis No: 14431

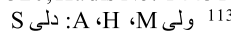

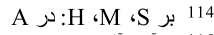

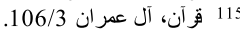

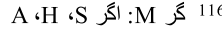

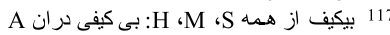


$\mathrm{A} 15^{\mathrm{a}}$

$\mathrm{M} 265^{\mathrm{b}}$

$\mathrm{A} 15^{\mathrm{b}}$

$\mathrm{S} 505^{\mathrm{a}}$

$$
\begin{aligned}
& \text { بىنظيرى شد جو خور او } 118 \text { از احد } \\
& \text { بىشبيه و بىنظير از فرد } 119 \text { بود }
\end{aligned}
$$

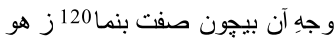

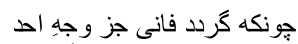$$
\text { شو ازين معنى بيان از آخهان }
$$

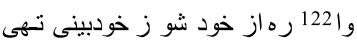

كه از اين معنى بيان او يهىبرد

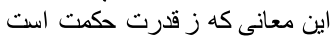

زين بيان معنوى شو مستمع

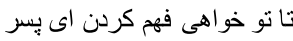

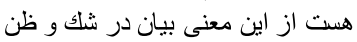
كز يقين دانى ورا بىاشتباه كى كند دانشورى ملَّت نـل دلى

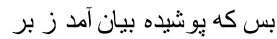

نو بيان نسبت ز اسرار كهن 123

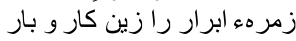

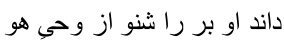

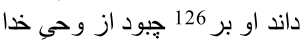

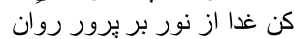
زان غداى بر دلت يرور بردنيست

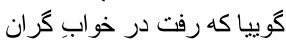
زان بكردم اين بيان را مختصر رئ دراب جز ازين معنى نسازم من كزين كان ز معنى رَمز و ايمانيا 129 كفتنيست فريت

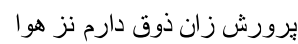

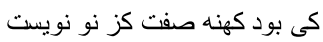

$$
295
$$

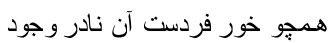

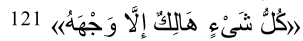

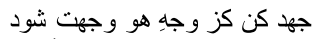
رو تو تركِ وجنهِ خود كن وجنه آنكهان

$$
300
$$

هر كه از خود شد رئ رهيده مئسزد

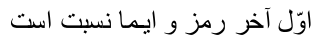

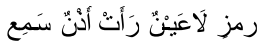

كى كند ادرالِ اين معنى بشر

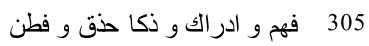

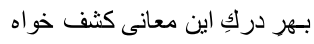

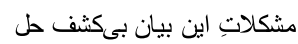

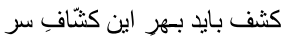

اوّل آخر سرّ برست اين سخن ائن ائن

310

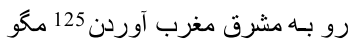

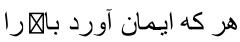

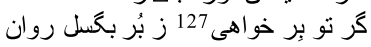

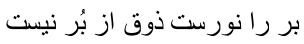
315 اي دريغا مستمع زينم بيان

جون نيابم أنن واعى ائ يّر

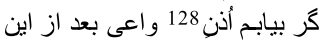

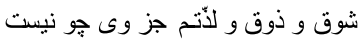

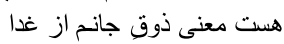

320 ذوق جانم زان غداى معنويست ذانت ازيت

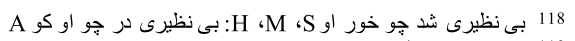

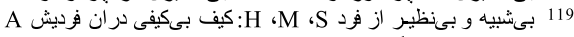
A كثتش 120 121

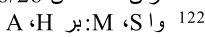
123 اين بيت در A در در حاشيه نوشته شده است.

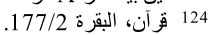
125

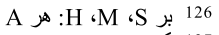
127 128

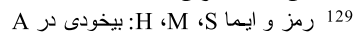




\section{Sonuç}

Çalışmamızda İbrahim Gülşenî’nin Farsça Divan'ı içinde yer alan Farsça tevhidinin, dört nüsha mukayese edilerek, tenkitli neşrini gerçekleştirdik. Tevhidin şekil ve içerik olarak incelenmesi ile şairin edebî ve tasavvufi kimliğine dair bilgiler sunulmuştur. Gülşenî'nin diğer Farsça eserlerinde olduğu gibi Divan'ında da Mevlânâ'nın tesirinin bariz bir şekilde görüldüğü gözlenir. İbrahim Gülşenî’nin Farsça Divan'ındaki bu manzumenin, aldığı dinî-tasavvufi eğitimin ve birikiminin bir nevi yansıması olduğu söylenebilir.

Gülşenî, çalışmamızın esasını oluşturan bu manzumesinde tevhidlerde olmazsa olmaz telakki edilen ayetler ve hadislerden iktibas yoluyla faydalanmakta; birtakım tasavvufi esaslara değinmekte ve kendi tasavvufi düşüncesine ağırlıklı olarak yer vermektedir. Allah'ın varlığı ve birliğini konu edinen edebî bir tür olarak tevhidlerde maksat hiç şüphesiz Allah'ın zatı, sıfatları ve fillerinden bahsederek Allah'1 övmekle birlikte tevhid bilincinin de yerleştirilmesidir. Gülşen̂̂’nin aldığı dinî-tasavvufi terbiye ve tahsil ettiği ilimlerle bu konuda yeterli birikime sahip olduğu açık bir şekilde görülür.

Gülşenî; İbn Arabî (ö. 638/1240), İbn Fârız (ö. 632/1235) ve Mevlânâ'nın (ö. 672/1273) düşünceleriyle şekillendirmiş olduğu vahdet-i vücûd anlayışının etrafında saliklere, visal yani Allah'a ulaşma yolunda bilinmesi gereken hakikatleri çeşitli nasihatler yoluyla aktarıken ayetler ve hadislerden faydalanmasının yanı sıra çeşitli benzetmeler ve metaforlarla da bu anlatımı zenginleştirerek anlatımını daha anlaşı1ır hâle getirmiştir. Bu vesileyle müritler için ilahi sırra ulaşmada rehber olabilecek bilgiler yanında Gülşeniyye tarikatı kurucusu ve mensubu olan İbrahim Gülşenî’nin bizzat yaşadığ 1 tecrübelerinden de haberdar olabilmekteyiz.

İbrahim Gülşenî’nin Farsça eserleri içinde tevhid türünde kaleme aldığ manzumesinin incelenmesi ve tenkitli neşrininin hazırlanması ile şairin edebî ve tasavvufi düşünce dünyasını anlamak, ona bağlı tarikatın adab ve esaslarını kavramak ve tarikat mensuplarının eserlerini yorumlayabilmek adına önemli bir katkının sağlanacağını ümit ediyoruz. 


\section{Kaynakça}

Abdulkerim Kuşeyrî (2012), Kuşeyrî Risâlesi, haz. Süleyman Uludağ, İstanbul: Dergâh Yayınları.

Akay, Mehmet (1996), İbrahim Gülşenî'nin Dîvânı: Metin-Dil Hususiyetleri-Sözlük, Konya: Selçuk Üniversitesi Sosyal Bilimler Enstitüsü: Yayınlanmamış Doktora Tezi.

Akben, Mesut (2012), "Dulkadirlide Bir Tarikat Şeyhi Şeyh İbrahim Gülşenî (Diyârbekir ?Mısır 1533)”, ed. Cevdet Kabakcı-Serdar Yakar, Uluslararası Dulkadir Beyliği Sempozyumu 29 Nisan-1 Mayıs 2011, S. 2, s. 487-502.

Ayverdi, İlhan (2005), Asırlar Boyu Tarihi Seyri İçinde Misalli Büyük Türkçe Sözlük: Kubbealtı Lugatı, nşr. Kerim Can Bayar, 3 C., İstanbul: Kubbealtı Neşriyat, (Çevrimiçi) http:// lugatim.com/ Kubbealtı Lugatı.

Azamat, Nihat (2000), “İbrahim Gülşen̂̂”, Türkiye Diyanet Vakfı İslam Ansiklopedisi, C. 21, İstanbul: TDV Yayınları, s. 301-304.

Bursalı Mehmet Tahir (2016), Osmanlı Müellifleri, haz. Mehmet Ali Yekta Saraç, C. 1, Ankara: Türkiye Bilimler Akademisi.

Canan, İbrahim (1988), Kutub-i Sitte Tercüme ve Şerhi, C. 7, Ankara: Akçağ Yayınları.

Çalka, Mehmet Sait (2017), “İbrahim Gülşenî ve Kıdemnâme Adlı Tasavvufî Mesnevisi”, Atatürk Üniversitesi Türkiyat Araştırmaları Enstitüsü Dergisi, S. 59, s. 119-154.

Ebû Abdullah Ahmed b. Muhammed b. Hanbel (1999), Müsned, thk. Şu'ayb el-Arnaût vd., Beyrut: Müessesetu'r-Risâle.

Ebû Bekir Ahmed b. el- Hüseyin Beyhakî (1990), Şuabu'l-İmân (I-VII), C. VII. Beyrut.

Erdem, Hüsamettin (1990), Panteizm ve Vahdet-i Vücûd Mukayesesi, Ankara: Kültür ve Turizm Bakanlığı Yayınları.

Esed, Muhammed (2009), Kur 'ân Mesajı: Meal-Tefsir, çev. Cahit Koytak, Ahmet Ertürk, İstanbul: İşaret Yayınları.

Hayrullah Efendi (1964), Hikâye-i İbrahim Paşa ve İbrahim-i Gülşenî, haz. Aytekin Yakar, Ankara: Ankara Üniversitesi Dil ve Tarih Coğrafya Fakültesi Yayınları.

İbn Sevre Tirmîzî (1978), el-Câmiu's-sahîh: Sünenü 't-Tirmîzî, tahkik ve şerh: A. M. Şakir, C. V, 2. bs., Kahire: Mustafa el-Babi el-Halebi.

İhvan Safa (1380), Fihrist-i Nâmgûy-i Nüshahâ-yı Hatt-ı Farsî Dârü'l-Kütüb-i Kahire, Kum: Kitâbhâne-i Ayetullâh el-Azmî Mar'aşî.

İsmail b. Muhammed Aclûnî (1351), Keşfu'l-hafâ, C. I, Beyrut: Dâru ihyâi't-turâsi'l-Arabî.

Karaman, Hayrettin; Özek, Ali; Dönmez, İbrahim Kafi (2017), Kur'an-ı Kerim Açıklamalı Me- 
ali, Ankara: Türkiye Diyanet Vakfı Yayınları.

Kızılcık, Abdullah (2006), Divânu İbrahim Gülşenî, Şam.

Konur, Himmet (2000), İbrahim Gülşenî: Hayatı, Eserleri, Tarikatı, İstanbul: İnsan Yayınları. (2002), “İbrahim Gülşenî’nin Pendnâme’sinde Tasavvufî Muhteva Örnekleri”, Dokuz Eylül Üniversitesi İlahiyat Fakültesi Dergisi, S. 16, Yaz-Sonbahar, s. 97-107.

Mahmud Cemaleddin el- Hulvî (1993), Lemezât-ı Hulviyye Ez Lemezât-ı Ulviyye (Yüce Velilerin Tatlı Halleri), haz. Mehmet Serhan Tayşi, İstanbul: Marmara Üniversitesi İlahiyat Fakültesi Yayınları.

Mevlânâ Celâleddîn Muhammed (2007), Mesnevî-i Ma'nevî, haz. Adnan Karaismailoğlu, Derya Örs, C. 2, Ankara: Akçağ Yayınları.

Muhyî-i Gülşenî (2014), Menâkıb-ı İbrâhim-i Gülşenî (İnceleme-Metin), yay. haz. Mustafa Koç, Eyyüp Tanrıverdi, İstanbul: Türkiye Yazma Eserler Kurumu Başkanlığı Yayınları.

Nev'izâde Atâyî (2017), Hadâ 'iku'l-Hakâ 'ik Fî Tekmileti'ş-Şakâ'ik Nev'izâde Atâŷ̂'nin Şakâ 'ik Zeyli, haz. Suat Donuk, İstanbul: Türkiye Yazma Eserler Kurumu Başkanlığı Yayınları.

Sami, Mehmed (1316), Esmâru Esrar, İstanbul: Cemal Efendi Matbaas1. http://isamveri.org/ pdfrisaleosm/R054604.pdf.

Sinsoysal, Betül (2017), İbrahim Gülşen̂̀’nin Türkçe Divanındaki Tasavvufí Kavramlar Üzerine Bir İnceleme, Eskişehir: Eskişehir Osmangazi Üniversitesi Sosyal Bilimler Enstitüsü: Yayınlanmamı̧̧ Yüksek Lisans Tezi.

Tek, Ayhan (2009), İbrâhim Gülşenî'ye Ait Mânevî Adlı Eserin Lâ'lî Mehmed Fenầ Tarafindan Şerhi, Van: Yüzüncü Y1l Üniversitesi Sosyal Bilimler Enstitüsü.

Terbiyet, Muhammed Ali (1377), Danişmendân-ı Azerbaycan, haz. Gulamrıza Tabâtabâî Mecd, Tahran: Sâzmân-1 Çâp u İntişârât-1 Vezâret-i Ferheng u İrşâd-1 İslâmî.

Uludağ, Süleyman (2012), Tasavvuf Terimleri Sözlüğü, İstanbul: Kitabevi Yayınları.

Uzun, Mustafa (1994), "Dede Ömer Rûşen̂̂”, Türkiye Diyanet Vakfi İslam Ansiklopedisi, C. 9 , İstanbul: TDV Yayınları, s. 81-83.

(2012), “Tevhid”, Türkiye Diyanet Vakfı İslam Ansiklopedisi, C. 41, İstanbul: TDV Yayınları, s. 24-26.

Yıldız, Alim (2002), “İbrahim Gülşen̂̂’nin Pendnâme'si”, Dokuz Eylül Üniversitesi İlahiyat Fakültesi Dergisi, S. 16, Yaz-Sonbahar, s. 57-95. 